\title{
Alguns aspectos da questão sanitária das cidades de Portugal e suas colônias: dos saberes olfativos medievais à emergência de uma ciência da salubridade iluminista
}

\section{Some aspects of the sanitary issue of the cities in Portugal and Portuguese colonies: from the medieval olfactory arts to the rising of an Illuminist science of the salubrity}

\section{Magnus Roberto de Mello Pereira}

Toto homine qui in calle aud in castello uel in carcaua iectare sterco pectet I morabitinum al concilio. Costumes e Foros de Castelo Bom, 1188-1230

A grande maioria dos autores apresenta a cidade medieval como uma espécie de inferno sanitário. ${ }^{1}$ Os indicadores disponíveis mostram um quadro propício à propagação de doenças: falta de luz e ar, monturos de lixo por todo lado e a contaminação generalizada das fontes de abastecimento de água. Uma das raras vozes a se manifestar em contrário a esta caracterização corrente foi a de Lewis Munford, que situa esse estado calamitoso especificamente na transição da Idade Média para a Idade Moderna, atribuindoo ao apinhamento populacional provocado pelas muralhas urbanas. ${ }^{2}$

O raciocínio desenvolvido por Munford não é, no todo, válido para Portugal. A maioria das muralhas portuguesas comportava muitos vazios e, mesmo assim, suas cidades tinham sérios problemas de sanidade urbana. $\mathrm{O}$ 
que se observa é que, mesmo nas vilas e cidades onde existiam vazios intramuros, havia um núcleo fortemente adensado e bastante insalubre.

Munford propõe um modelo específico de crescimento urbano medieval em que a cidade, numa primeira fase, se expande mantendo uma boa quantidade de áreas não edificadas. Apenas numa etapa posterior, o crescimento horizontal, e supostamente harmonioso, seria detido pela barreira das muralhas, o que provocaria uma densidade excessiva de ocupação. Nessa fase ocorreria a verticalização da cidade e o aproveitamento da profundidade do lote para construções, com a consequiente redução dos quintais e o agravamento da insalubridade.

Em Portugal, o processo parece ser um pouco diferente. Existiam no interior das muralhas medievais núcleos prévios de adensamento, muitas vezes conformados por muros mais antigos, os quais podem ser qualificados como o urbano propriamente dito, em oposição às reservas de terras intramuros e aos espaços rurais circundantes. $\mathrm{O}$ crescimento se dava pelo avanço deste núcleo adensado sobre as áreas de reserva. Se observarmos a iconografia das cidades medievais, veremos que elas eram representadas como unidades muito compactas e desligadas do entorno, o que demonstra que o apinhamento urbano era um valor em si. A cidade compacta era algo perseguido pelos moradores e não o resultado de um processo de adensamento que escapara de controle. Era exatamente este adensamento que caracterizava e definia a aglomeração urbana medieval.

Tomemos como exemplo as bastides medievais. Por serem planejadas, elas se aproximavam daquilo que, na época, seria considerado um assentamento urbano desejável. As suas ruas eram mais retilíneas e largas do que as das cidades que haviam crescido lentamente, mas, mesmo assim, eram cidades muito compactas que não deixavam espaço para a interpenetração entre o urbano e o rural envolvente. O que pretendemos ressaltar com essa argumentação é que o apinhamento é tanto algo desejável como uma tendência geral observável na cidade medieval, que os limites impostos pelas muralhas não criam, mas apenas agravam.

São muitos os fatores que levavam a esse tipo de escolha, a começar por um de ordem simbólica. A cidade definia-se em oposição ao campo circundante e não como o resultado do crescimento de um núcleo rural. Entretanto, nesta maneira de organizar o espaço urbano pesavam, também, 
motivações de ordem econômica. O compartilhamento de paredes tornava mais barata a construção de casas. Os almotacés medievais da Península Ibérica tinham como uma de suas principais atribuições a de mediar os conflitos entre vizinhos, provocados, justamente, pelo compartilhamento de paredes lindeiras. Também se inscreve na órbita econômica a tendência a aumentar a renda da terra urbana através da maximização do uso do lote. Desde o final da Idade Média, a nobreza portuguesa buscou complementar a renda agrícola com outras provenientes da nascente urbanização, entre elas as propiciadas por casas urbanas construídas para arrendamento. A existência de moradias exíguas e superocupadas, geradas pela especulação imobiliária, é um fenômeno mais antigo do que costumamos supor.

No processo de adensamento das cidades medievais pesou, ainda, um aspecto defensivo. Uma das características mais marcantes da cultura medieval era o medo, que se expressava, também, na tendência a construir espaços fechados. O bloco compacto de casas era considerado como uma unidade de defesa: a única no caso de um conjunto de casas sem muralhas, o último reduto no interior da fortificação, quando ela existia. Tanto a prática militar medieval, quanto a própria legislação, levavam tal aspecto em consideração. Mais tarde, nas colônias, esta foi uma questão sempre presente entre os agentes da coroa, o que os levaria a pressionar os moradores a manterem juntas as suas casas.

A cidade dispersa e salubre que Munford tenta nos mostrar é mais a ausência da cidade ou aquilo que mal é cidade. Ele esgrime contra aqueles que procuram mostrar o estado de insalubridade calamitosa da cidade medieval madura uma suposta bonomia à sua nascença, um estado característico da aldeia onde rural e urbano se interpenetram. Munford parece não se dar conta de que muitos dos problemas de salubridade enfrentados pela cidade medieval e moderna eram resultado da tentativa por parte dos moradores de manter esta interpenetração. Ainda que tivesse crescido e procurasse definir-se como urbana, esta cidade foi, por séculos, pouco urbana justamente por manter em seu interior muito do mundo rural.

O fenômeno da urbanização medieval é um fazer de novo. Urbanizase com pessoas recém-saídas do campo. Não importa, aqui, se elas viviam isoladamente ou na diminuta aldeia proposta por Munford, pois, independentemente dessa questão, naquilo que nos interessa, o resultado é o mes- 
mo. Aqueles que chegavam à cidade acabavam de sair de uma economia de auto-subsistência e de um fazer cotidiano rural. Enquanto permaneceram no campo, esses camponeses medievais usavam os próprios excrementos e os dos animais de criação como adubos. Por terem um valor utilitário imediato e reconhecível, os dejetos não eram vistos como contaminantes ou nocivos à saúde e, talvez, nem fossem malcheirosos. Não é comum, até hoje, apreciarmos os bons odores do campo? Da mesma forma, os rejeitos em geral ou eram adubos ou eram forragens e lavagens: comida de aves ou porcos. Outras formas de lixos, se é que existiam, eram produzidas e descartadas numa velocidade que permitia a sua regeneração pela ação do entorno, sem que houvesse tempo para acúmulos.

Pensemos, agora, na situação urbana. No período que nos propomos a estudar, compreendido pelo que convencionalmente costuma-se denominar por Baixa Idade Média e Idade Moderna, uma boa parcela do processo produtivo permaneceu no campo. Entretanto, à medida que a urbanização avançou, formou-se uma camada de pessoas que moravam na cidade mas que mantinha hábitos de consumo próprios da economia rural dominante, com a qual deparava-se toda vez que deixava as muralhas urbanas.

Os hábitos de consumo rural conformam um espaço contíguo à casa onde se desenrola parte importante das atividades domésticas e econômicas. É no terreiro ou no passal que se faz o preparo final dos alimentos tanto para o consumo imediato - limpeza, descasque ou trituração - como para sua conservação — secagem, salga ou defumação. São exatamente as atividades dessa fase final do consumo que o morador da cidade, preso ainda a hábitos rurais, procura trazer para junto de sua casa urbana. Na medida do possível, ele tenta reproduzir esses espaços, agregando à sua casa equivalentes urbanos dos terreiros. São os quintais, varandas ou terraços, espaços indispensáveis ao desenrolar do quotidiano medieval e da era moderna. Os diversos fatores que conduzem ao apinhamento da cidade fazem com que esses correspondentes urbanos fiquem aquém do necessário. A conseqüência é que as ruas e praças sejam apropriadas como passais ou terreiros.

De qualquer forma, ainda que houvesse uma apropriação das ruas, a separação entre produção e consumo, própria da condição urbana, não permitia o total processo de reciclagem que ocorria na economia camponesa. O espaço urbano simplesmente não dava conta de digerir tais restos associa- 
dos ao consumo. Foram os detritos, mais os excrementos produzidos pelos moradores, que instauram na cidade o reino do pútrido. A cidade foi a grande inventora dos cheiros nauseabundos. A economia camponesa não gerava esses odores, pelo menos não na escala em que passariam a ser produzidos no espaço urbano. Simultaneamente ao pútrido, instalou-se na cidade medieval o reino da peste, o que levaria os moradores a estabelecer uma interconexão de causa e efeito entre ambas as coisas. A podridão orgânica dos dejetos urbanos era apontada como a principal causa do adoecimento dos habitantes. Era o que nos dizia o regimento dado por D. João I a Évora, em 1392: "Porque das sujidades e estercos e coisas podres e nojosas e fumos que se delas fazem nos lugares recrescem muitos danos e dores aos corpos."

As críticas feitas àquilo que nos propõe Munford não significam uma total discordância com o autor. Ainda que não compartilhemos de sua aversão à cidade contemporânea, ou de sua tentativa de resgate romântico da cidade medieval, é preciso reconhecer a sua importância por ter trazido para o centro das atenções o problema da ambiência ou da salubridade urbana. Ainda hoje, a maior parte da produção historiográfica sobre a cidade relega a questão da salubridade à condição de curiosidade ou de aspecto ilustrativo. Os estudos produzidos pelas ciências sociais e econômicas, de tanto abordar as motivaçôes da cidade (suas "causas" socioeconômicas) e os seus resultados (as "consequiências") acabam esquecendo que o habitante da cidade teve que construir a própria possibilidade de ela existir, processo no qual a salubridade tem um papel capital. A cidade não se fez apesar dos problemas de salubridade, mas com eles.

Atualmente, a percepção de que a (in)salubridade é constitutiva do urbano tende a ser ocultada pelos mesmos fluxos invisíveis estabelecidos por um conjunto de tecnologias que procuram banir os dejetos do alcance da vista e do olfato. A abordagem deste tema não é motivada por uma curiosidade pelo escatológico. As cloacas da cidade vão ser abertas, não em busca dessas soluçōes tecnológicas aprimoradas para produzir o ocultamento, mas na tentativa de dar visibilidade a certos aspectos do fazer-se urbano.

\section{As pestenenças}

$\mathrm{Na}$ Europa, o século XIV foi o século das grandes pestes que, em muitas localidades, levaram mais da metade da população. Esta debacle popu- 
lacional provocou uma profunda renovação das estruturas sociais e da distribuição da riqueza, as quais, para muitos autores, sinalizam o fim do período medieval. Também, em decorrência dessas epidemias, observa-se uma tomada de consciência da insalubridade urbana que desembocaria na produção de normas de controle e na introdução de medidas práticas que objetivavam a melhoria das condições sanitárias das cidades. Em Portugal não foi diferente. As epidemias também assolaram as cidades da Península Ibérica, o que levou tanto os reis portugueses como os conselhos municipais a adotarem medidas muito semelhantes às prescritas no resto do continente. Tal quadro de propostas e práticas que a coroa e as municipalidades adotaram com o intuito de debelar as pestes e melhorar o estado sanitário das cidades era orientado por uma concepção eminentemente olfativa de salubridade.

A produção historiográfica costuma associar a emergência da sociedade burguesa, que se inicia com a reurbanização da Europa tardo-medieval, a uma negação do sentido do olfato. Todavia, quer me parecer que há nisso uma boa dose de esquematismo e simplificação do problema. Se, antes da reurbanização do ocidente, havia uma maior competência olfativa, esta competência seguramente não estava voltada para o mefítico. Por séculos, o morador da cidade medieval e moderna esteve condenado a tais cheiros que a seqüência de epidemias inaugurada pela peste negra fez associar à doença e à morte. Se a convivência secular com as imundícies urbanas pode ter levado a um aumento da tolerância olfativa, por outro, essa mesma convivência tornava necessário que não se perdesse a capacidade de reconhecer os maus odores. Segundo o que se acreditava na época, a própria sobrevivência individual e coletiva dependia desta capacidade. A relação que se estabeleceu entre o morador da cidade e as suas esterqueiras era, portanto, ambígua. Ela oscilava entre a convivência pacífica e o pavor, oscilação ditada principalmente pelo ritmo das epidemias. Não se deve, assim, estranhar que essa sociedade tenha desenvolvido precocemente uma "ciência" olfativa da salubridade urbana na qual se apoiavam as medidas emergenciais adotadas com o intuito de debelar as pestes.

\section{Abrir ou fechar, fugir ou ficar}

As grandes epidemias da Idade Média fizeram com que retomasse consistência um dos mais antigos programas do viver urbano: o afastamento da 
podridão e dos maus-cheiros. É certo que esse grande objetivo não foi perseguido com a mesma intensidade e persistência em todas as épocas e lugares, mas os periódicos surtos de "pestenências" obrigavam a manter o pútrido na agenda das preocupações.

Ao estudar a atuação dos conselhos medievais portugueses diante das pestes, a historiadora portuguesa Maria José Tavares nos mostra que o primeiro dilema enfrentado pelos habitantes das cidades era o de ficar ou partir. ${ }^{4}$ Todavia, tal tipo de solução era ainda uma decisão pessoal, ao alcance de poucos. El'Rei D. Duarte, em seu Leal Conselheiro, diria que "cousa perigosa é escolher homem estar no lugar onde morrem de pestelença, é coisa mais segura partir-se". Entretanto, apenas a elite tinha meios e poder para empreender a fuga, uma atitude que muitas vezes mostrava-se inútil. $\mathrm{Na}$ peste de 1438 , o próprio D. Duarte fugiria, em vão, de Lisboa, pois a morte iria alcançá-lo em Tomar.

Muito cedo, as opções pessoais com que se enfrentavam as pestes seriam condicionadas por decisões tomadas na esfera pública. $\mathrm{O}$ rei e os conselhos passariam a decidir entre fechar ou abrir as cidades e as casas, entre obrigar a partida ou a permanência, com o que a doença deixaria de ser um acidente pessoal para tornar-se acontecimento ligado à esfera de decisóes estatais. Se a isso podemos chamar de emergência das políticas públicas sanitárias é outro caso.

\section{0 mau ar, que é grande impedimento}

A noção de que a decomposição da matéria orgânica era capaz de ser transmitida através do contato, causando o apodrecimento dos corpos vivos — as doenças —, tem longa história na tradição ocidental. Também não era nova a idéia de que o ar e as águas tivessem a capacidade de transmitir a contaminação pútrida. A Idade Média não inventou essas noções, assim como não optou por nenhuma das duas em exclusivo. Ambas desempenharam papéis decisivos na definição das práticas públicas de saneamento.

Nos momentos agudos, quando a pestenença ameaçava entrar ou já tinha entrado em alguma cidade, a noção de contágio direto ganhava relevância. A de contágio indireto também orientava algumas ações nesses momentos, mas é possível sentir todos os seus efeitos como norteadora 
daquilo que, hoje, denominaríamos profilaxia. É ela que informa a maior parte das posturas municipais destinadas a sanear o espaço urbano. Mais freqüentemente, as medidas adotadas nos mostram que há uma hesitação ou embricamento entre as duas maneiras de encarar a contaminação. Uma carta de D. João II, endereçada à Câmara de Lisboa, nos dá mostra da oscilação entre as duas estratégias de enfrentar a peste no final do século XIV. Cada uma derivada de um dos princípios acima mencionados.

E o que nos parece deveis fazer é que mandeis apregoar que onde quer que adoecer alguém que o digam, pondo-lhe todas as penas que bem parecer, as quais todas aprovaremos. E nas casas onde assim adoecerem não devem ser cerradas, como se costuma fazer, mas devem ser despejadas e muito bem varridas e lavadas com vinagre e perfumadas com alecrim por algumas vezes com janelas abertas, por sendo cerradas fica sempre aquele mau ar dentro, que é grande impedimento. E [....] depois desta diligência assim fizerdes nas ditas casas doentes, fazei pôr às portas das ditas casas ou janelas onde bem parecer cada uma seu ramo d'alecrim ou outro sinal algum para se saber a casa onde adoeceram e seja causa de se arredarem, de irem por aquele lugar. ${ }^{6}$

Fechar ou abrir? Eis a questão. $\mathrm{O}$ medo do contágio pelo toque recomendava o enclausuramento dos doentes e seus familiares em suas próprias casas ou em lugares fora da cidade. Em casos extremos chegava-se a emparedar regiōes inteiras da cidade, como aconteceu com a rua do Olival, no Porto, ou com a judiaria de Évora, em finais do século XV. Prática que ofendia a sensibilidade cristã da época, pelo sacrifício que impunha a muitos "inocentes", além de gerar atitudes de resistência entre os moradores atingidos.

Afora tal dilema ético, a questão complicava-se pela crença de que a atmosfera desses locais fechados corrompia-se. Ao trancafiar-se o doente, trancava-se simultaneamente o ar corrupto, mantendo, desta forma, um foco de contaminação permanente dentro da cidade. Em nosso exemplo, o rei opta pelo arejamento, contrariando, como ele mesmo diz, a solução mais corrente do entaipamento das casas dos doentes. Complementando a aeração dos ambientes, a ordem real prescrevia mais alguns cuidados: a desinfecção com vinagre e o uso de perfumes como contra-aromas que ajudariam a purificar o ar pestilencial. Por via das dúvidas, a casa era marcada com um ramo de alecrim para que ninguém se aproximasse, de maneira a evitar qualquer contato com o imóvel contaminado. 
Desde o século XIV, quando, com mais freqüência, passou-se a adotar a estratégia do arejamento, as medidas mais utilizadas para sanear as cidades atingidas por surtos eram, resumidamente, as que acabamos de ver: evacuação e limpeza dos edifícios, dispersão de perfumes. Outra preocupação era dar rápida sepultura aos cadáveres.

Antes, porém, que a peste chegasse à cidade, outras medidas já haviam sido tomadas. Quando se espalhava a notícia de que o flagelo se aproximava, a primeira medida era tentar impedir qualquer contato com moradores ou pessoas provenientes de lugares contaminados. A grande preocupação era com aqueles que fugiam e buscavam abrigo na casa de parentes e amigos em localidades ainda não atingidas. Se alguém abrigasse algum desses fugitivos seria multado e expulso junto com o presumível disseminador da epidemia.

Ouvide. Mandado do corregedor e vereadores e procurador e homens bons da mui nobre e sempre leal cidade de Lisboa, não seja nenhuma pessoa tão ousada, de qualquer estado e condição que seja, que for desta cidade para alguma parte fora dela ou vier dalgum lugar e lhe der esta enfermidade de pestelença, que Deus apraza de alevantar, pague de pena 500 reais brancos e quem quer que agasalhar em sua casa pague outros quinhentos reais e seja lançado fora dela. ${ }^{7}$

Uma última solução, adotada em alguns casos extremos, era a de evacuar totalmente a cidade. Esse ato desesperado era acompanhado da adoção de medidas destinadas à purificação do ar. Acendiam-se fogueiras, espalhavam-se ervas e perfumes e traziam-se os animais de pasto para dentro da cidade. Acreditava-se que a respiração destes animais tinha a propriedade de purificar o ar corrompido pelas emanações pestilenciais.

Ao lado de todas essas medidas sanitárias, as autoridades eclesiásticas recomendavam algumas outras. Rezar e rezar e fazer penitências. Peste e pecado ainda não eram coisas dissociadas.

\section{Esta vossa terra não perdoa ninguém}

No primeiro momento da expansão marítima portuguesa, o panorama sanitário não sofreria alterações de monta. Quer no Norte da África, quer nas ilhas temperadas ao norte do Atlântico, repetia-se o quadro das 
pestenências européias. Os arquipélagos dos Açores e da Madeira eram desabitados e os colonos ali instalados trouxeram consigo tanto as pestes quanto os hábitos higiênicos europeus.

De Cabo Verde para baixo as coisas mudariam de figura. Com o aumento das distâncias e do tempo das viagens, os navegantes viram somar-se o escorbuto a todas as pestes que traziam consigo. Os navios eram o reino do pútrido: gengivas podres, águas podres, alimentos podres. Lançar corpos ao mar era uma das mais constantes rotinas das viagens. Chegava-se finalmente aos trópicos, onde os viajantes acreditavam que as pestes européias não grassavam.

Primeiramente, é de notar como aqui é o princípio dos Etiópios e homens negros; e porque são duas Etiópias, bem é que se saiba como esta primeira se chama Inferior ou Etiópia Baixa Ocidental, na qual é certo e sabido que nunca nela em algum tempo morressem de pestelência; e não tão somente tem este privilégio que lhe a majestade da grande natureza deu, mas ainda temos, por experiência, que os navios em que para aquelas partes navegamos, tanto que naquele clima são, nenhuns homens dos que neles vão, desta enfermidade morrem, posto que desta cidade de Lisboa, sendo toda deste mal, partam e neste caminho alguns aconteçam de adoecer e outros morrer; como na Etiópia são, nenhum dano recebem. ${ }^{8}$

Se a experiência, "madre de todas as coisas", ensinava que a pestelença talvez não resistisse aos climas tropicais, ensinava, também, sobre novos contágios. Do rio Senegal para baixo, os roteiros de viagem anotam repetitivamente o perigo das febres. Em um comentário sobre a feitoria de São Jorge da Mina, o cosmógrafo Duarte Pacheco Pereira menciona o quanto a África era letal para aqueles que vinham da Europa, mas lembra também porque era preciso correr o risco. "Neste trato que aqui é dito se ganha cinco por um e mais. Mas esta terra é muito doentia de febres e razoadamente morrem aqui os homens brancos."

Contra tudo o que haviam afirmado os clássicos da antiguidade, a zona tórrida era habitável. ${ }^{10}$ Sim, a vida era possível entre os trópicos e ali foram sendo instaladas diversas feitorias e colônias. Mas, para se viver nesta regiāo, havia um alto preço a pagar.

Os habitantes brancos da Povoação [São Tomé], ordinariamente em todo ano, todos os oito ou dez dias, sofrem uma espécie de sezão, isto é: 
primeiro o frio, depois a febre, e em duas horas passa tudo, segundo a compleição que têm. Este acidente acontece àqueles que habitam ali de contínuo, os quais se sangram três ou quatro vezes ao ano; porém, os estrangeiros que ali vêm com navios, a primeira febre que os acomete é mortal, e costuma-lhes durar vinte dias. Sangram-se sem conta de onças, tirando da veia do braço quase um pichel, e quando estão sangrados, lhes fazem uma sopa de pão em água, sal e um pouco de azeite e se passam o sétimo dia, esperam ainda o catorzeno e depois o dão por salvo. ${ }^{11}$

Quem nos descreveu esses constantes acessos de malária foi um piloto anônimo da frota que, na primeira metade do século XVI, ia buscar açúcar no arquipélago equatorial de São Tomé. Tal como ele descreve, parece estar em curso um processo darwiniano de seleção. Somente àqueles que sobrevivessem ao primeiro impacto microbiano seria dada a oportunidade de crescer (pois muitos dos colonos de São Tomé não passavam de crianças), multiplicar (pela cópula desenfreada com as escravas) e acumular as riquezas das conquistas. Todavia, enganara-se o piloto anônimo: escapar à primeira febre não era garantia de longa vida. O capitão-donatário que deu impulso à colonização de São Tomé resistiu-lhe seis anos, mas, finalmente, chegou o seu dia.

Adoeceu Álvaro de Caminha, de febres, as quais teve 12 ou 15 dias, de que foi são. E andou assim uns dias, até que um dia, mandando por um navio em monte, com a fadiga que nisso levou e grandes calmas, tornou outra vez a cair de febres, que o não deixaram, até que, passados $10 \mathrm{ou}$ 12 dias, lhe tiraram a alma. ${ }^{12}$

Junto com a do capitão, perderam-se as almas da maior parte de seus insólitos colonos, as crianças judias, devoradas pelas febres, pela fome e pelos enormes "lagartos" que infestavam as ribeiras santomenses.

Na vizinha Ilha do Príncipe, conforme se observa na carta escrita pelo preposto de outro donatário, as coisas não eram diferentes.

Eu Senhor fui muito doente, e não de muitos dias, Deus seja louvado. Porém de corrimento me trata a ilha mal. Beijarei as mãos de vossa mercê mandar quem nela fique, porque estes dois anos basta para mim vos nela servir, porque é razão ir por ver minha casa e filhos e ofícios de que não recebo nenhum proveito ao presente. Não lhe dou Senhor mais conta de sua fazenda porque o deixo já para quando embora for. 
Senhor, o mestre dos ferreiros é falecido e o calafate acaba para este ano, ainda que fica com a candeia na mão. Tenha vossa lembrança de o prover para o ano. E também o barbeiro que eu fiz vir comigo também esta do bordo do calafate. Um Francisco Lopes vosso morador e outros dois e um criado meu que me veio de Portugal depois de vossas naves partidas faleceram, e crede que essa vossa terra não perdoa ninguém.

Ilha do Príncipe, 24 de agosto de $1517 .{ }^{13}$

O primeiro momento da ocupação do arquipélago de São Tomé foi apenas um dos muitos capítulos trágicos da experiência portuguesa de colonização dos trópicos. Os colonos foram praticamente largados à própria sorte a apodrecer num mundo desconhecido para o qual estavam despreparados. As sementes trazidas de Portugal não germinavam, ou, quando o faziam, as plantas que nasciam eram de viçosas folhas, mas sem frutos. Perdiam-se as colheitas por se desconhecer os solos tropicais ou o regime de chuvas. As febres faziam vítimas fáceis entre uma população depauperada pela fome. O socorro demorava a chegar de Lisboa e, quando finalmente chegava, triste constatação: os suprimentos vinham todos podres, conduzidos por marinheiros doentes, que, em vez de ajuda, tornavam-se pesado encargo para os famintos colonos.

A morte de Álvaro Caminha, o donatário de São Tomé, não é um caso isolado, mas pertence a uma vastíssima galeria de ilustres figuras consumidas pelas pestes tropicais. Afonso de Albuquerque, morto pela corrupção dos ares de Goa, Paulo Dias de Novais, conquistador de Angola, consumido pelas febres em Massangano. Nas colônias tropicais, onde quer que se observe, a mortandade do homem branco se repete indefinidamente.

No Índico, os grandes flagelos eram as letais disenterias. Goa sofreu sucessivos surtos de cólera. Durante a epidemia de 1570, numa tentativa infrutífera de sanear a cidade, foram soltos os animais de pasto para a limpeza dos ares contaminados. ${ }^{14}$ Devido à ineficiência dos remédios europeus, a câmara da capital portuguesa do oriente chegaria a criar uma legislação contra os farmacêuticos da cidade, suspeitos de fraudarem os medicamentos.

No Brasil, a principal peste era a varíola. A bexiga, como ficou conhecida, foi trazida pelos colonizadores europeus e encontrou campo fértil entre uma população nativa desprovida de defesas. Todavia, ela não ficou restrita à população indígena. Em decorrência da varíola, desde o início do 
século XVII, adota-se inspeção dos navios que se aproximavam do porto de Salvador. Em 1626, um navio proveniente de Angola foi impedido de atracar e os seus tripulantes mantidos em quarentena na Ilha dos Frades. No mesmo ano, o Senado da câmara votara a primeira legislação sanitária adotada na cidade. ${ }^{15}$ Em 1663, Salvador sofreu mais um letal surto de varíola.

Poucos anos depois - 1686 - a cidade foi atingida pela primeira grande epidemia de bicha, a febre amarela, um novo gênero de peste que, segundo o Padre Vieira, nunca havia sido visto pelos médicos. Morreram as principais autoridades coloniais, inclusive o arcebispo Frei João da Madre de Deus e o governador-geral do Brasil, Matias da Cunha. Nas palavras de Afonso Ruy, o historiador da câmara soteropolitana, conhecemos as medidas adotadas pela municipalidade com o intuito de debelar o mal. "Alimparase a cidade, removeram-se os esterquilínios, destruíram-se os monturos e, para purificarem-se os ares, por ordem do governo, manadas de bois, trazidas dos pastos próximos, enchiam as ruas, aproveitando-se os seus excrementos em cremações constantes, como forma de saneamento." ${ }^{16}$ Como se percebe, para as novas pestes exóticas as velhas medidas adotadas desde a peste negra de 1348.

\section{Água vai}

Lisboa no século XV, Goa no XVI, Salvador no XVII, a cada surto de alguma pestenência, concomitantemente às medidas emergenciais adotadas na tentativa de debelar o flagelo, reforçava-se a noção de que viver na cidade comportava os seus perigos. Já no século XVII, constatando o hábito das famílias ricas morarem em residências secundárias fora do quadro urbano — as quintas de recreio —, Francisco Manuel de Melo mencionava os benefícios de ausentar-se da cidade:

Estas ausências trazem grandes e muitos proveitos à vida, à saúde, à fazenda, à salvação. À vida porque no campo se vive mais; à saúde porque seus exercícios a conservam; à fazenda porque se gasta menos; à salvação, porque faltam as ocasiōes porque a arriscam, anda o ânimo mais livre para cuidar em Deus, e em si mesmo. ${ }^{17}$

Viver numa quinta de recreio era, de certa forma, a reinvenção das fugas medievais das cidades tomadas pelas pestes: uma forma privada de 
enfrentar a insalubridade urbana. Na alçada dos poderes públicos, a mesma noção dos perigos da putrefação da atmosfera da cidade desemboca na produção de leis preventivas. As câmaras municipais foram responsáveis por uma farta produção de degredos e posturas voltadas a extirpar os monturos de lixo, ao desentupimento de canos e à preservação das fontes de abastecimento de água. As posturas, em oposição às práticas emergenciais, buscavam ter um caráter permanente e, independentemente de serem respeitadas ou não, podem ser consideradas como textos formuladores de regras constitutivas de comportamentos urbanos considerados aceitáveis.

Em decorrência dos surtos de pestes e com base no saber olfativo, as câmaras municipais iriam elaborar uma legislação voltada, especificamente, ao saneamento das cidades, mas que levaria a desdobramentos insuspeitos no que respeita ao viver urbano. A própria polissemia da palavra urbano dá indícios da problemática em questão: urbano é tudo aquilo que diz respeito à cidade, mas, ao mesmo tempo, é um modo de comportamento. Viver na cidade implica uma urbanidade, termo que os dicionários apresentam como sinônimo de civilidade. Quando examinamos os textos normativos elaborados pelo poder municipal, percebemos que o sanitário é um dos componentes fundamentais na construção desta urbanidade. ${ }^{18}$

\section{Qualquer pessoa que fizer seus feitos na praça}

Não causa incômodos maiores a afirmação de que a questão dos lixos e excrementos seja uma das melhores para se discutir o tema da urbanidade ou civilidade. Há séculos a limpeza vem sendo tomada como indicador geral de civilidade. Segundo esse critério, os habitantes das cidades, ou mesmo povos inteiros, seriam civilizados em maior ou menor grau de acordo com a limpeza corpórea ou do ambiente em que vivem. Entretanto, a muitos pareceria estranha a afirmação de que essas mesmas questões permitem abordar o processo de compartimentação da vida em esferas públicas e privadas.

A condição de morador da cidade impõe um duplo movimento no que respeita ao destino dado aos excrementos e outros dejetos. O primeiro deles é o da privatização ou domesticação desses resíduos, o qual deriva do reconhecimento do poder contaminante nos mesmos. O segundo é o de torná-los públicos, o que deve ser feito segundo normas expressas de urba- 
nidade. Esse duplo movimento tende a consolidar a separação da vida em duas esferas. Uma ação doméstica perfeitamente 'natural', como varrer para fora de casa algumas poucas sobras, que, no campo, seriam imediatamente consumidas pelos animais do terreiro, torna-se, na condição urbana, um ato de ruptura de uma fronteira que passa exatamente na soleira da porta. Ultrapassado o limiar da porta ou da janela, entra-se num outro universo: o do público.

170 - Item - Não lançarão escamas do pescado nem de sardinhas nas ruas nem terão cisco às portas sob pena de cinqüenta réis. ${ }^{19}$

A construção da urbanidade implica, inicialmente, a privatização dos dejetos, sejam eles excrementos ou resíduos domésticos ou de atividades econômicas. Exatamente porque a cidade não está aparelhada, física ou institucionalmente, para tratar dos excrementos e lixos, torna-se necessário estabelecer o vínculo entre eles e os produtores dos mesmos, mantendo-os na esfera privada.

892 - Qualquer pessoa que fizer seus feitos na praça ou em ruas e quelhas públicas, se for homem ou mulher, pagará trinta réis, e se for moço ou moça, pagará dez réis. E porém isto se não entenderá em meninos de quatro anos para baixo. ${ }^{20}$

Não devemos, portanto, estranhar que na língua portuguesa a noção abstrata de privado tenha se tornado concreta nos objetos e locais onde se depositam as fezes. Para um português medieval, o privado nada mais é do que o penico e a privada, ou secreta, o local onde se defeca. ${ }^{21}$

Todavia, o reconhecimento de que, no limite, a solução privada é impossível, leva a que o lixo e os excrementos ganhem uma dimensão social e sejam encarados como um ônus do viver urbano. Configurando o segundo momento do movimento dos dejetos, eles necessariamente voltam ao público. Mas, para voltarem, devem obedecer a determinadas regras que desonerem a cidade ou que minimizem ou camuflem a sua existência.

165 - Item - Defendemos que nenhuma pessoa lave privados senão do padrão que está defronte da casa onde se mata a carne para baixo e qualquer pessoa que do dito padrão para cima lavar privado pagará oitocentos réis da cadeia, metade para a cidade e a outra para quem os acusar. 
E levarão os ditos privados cobertos sob pena de cinqüenta réis. Coimbra, século XV. ${ }^{22}$

Como se percebe pelo exemplo, a passagem dos excrementos pelo espaço público deveria respeitar um código de etiqueta excrementícia. Em algumas cidade, como Coimbra ou Évora, tal código era mais detalhado, em outras, mais simples, e se resumia à mais difundida das regras desta etiqueta: a obrigação de gritar "água vai”, sempre que algum líquido fosse atirado da casa para o espaço público.

816 - Quem lançar água nas ruas sem dizer água vai três vezes se for de noite pagará cinqüenta réis e de dia dez réis. E se tal água que deitar de dia for fedorenta pagará os ditos cinqüenta réis. $\mathrm{E}$ os que em tais penas incorrerem serão os senhores da tal casa sempre citados em pessoa e demandados. E se se a dita água lançar de noite o jurado que a tal água encoimar será obrigado a catar ${ }^{*}$ a porta ou janela donde vir que se lançou a tal água.

Coimbra, século XVI. ${ }^{23}$

Uma particularidade da legislação municipal de Coimbra, que também ocorria na de Évora, era a distinção entre estercos e cisco — os lixos em geral - e aqueles contidos nos "privados", os recipientes para os excrementos. Em relação às águas, a legislação municipal coimbrã procurou estabelecer uma diferenciação. $\mathrm{O}$ lançamento das águas servidas à rua, como em todas as outras cidades, deveria ser precedido do grito de "água vai", enquanto o lançamento de urina estava proibido por dispositivo específico. "Não lançarão urina nem água fedorenta nas ruas sob pena de cem réis", previam as posturas. ${ }^{24} \mathrm{Em}$ outras localidades, a legislação era bem mais tolerante. Em Braga, já no século XVIII, a proibição do lançamento de "águas imundas ou fétidas" vigorava apenas até as 11 horas da noite, a partir do que estava liberado. ${ }^{25}$

É certo que a desobediência aos códigos municipais foi generalizada. Contudo, percebe-se que, lentamente, eles produzem efeito até atingirem o seu ponto de maior eficácia quando passam a ser obedecidos não por serem leis, mas por se transformarem em prática social corrente, o costume. No caso dos excrementos, o controle internalizado assume outras formas como "pudor" ou "educação". É o que se observa no relato de um viajante inglês, 
que no final do século XVII passou pela Madeira. Estabelecendo uma oposição ao que ocorria em sua terra de origem, John Ovington louvou os bons hábitos higiênicos que vigoravam nas reuniões sociais promovidas pela elite madeirense.

Quando a reunião se interrompe, são utilizados como mictórios certas partes nos átrios e entradas das casas e, muito especialmente, um recanto privada atrás da porta, isto porque urinar na rua é considerado indecente. ${ }^{26}$

Neste caso específico, já não se urinava na rua porque era ilegal, mas porque era indecente.

\section{Que nenhuma pessoa faça esterqueiras}

As formas de lidar com o lixo urbano e com os excrementos, prescritas tanto pelas câmaras quanto pela coroa e seus emissários, derivavam diretamente do conceito de contaminação do ar que estabelecia uma correlação direta entre saúde e odores. Tudo que exalasse cheiros considerados desagradáveis era apontado como foco potencial de doenças. ${ }^{27}$ Em decorrência, as estratégias de detecção e combate às doenças eram eminentemente olfativas. Era pelo odor que se detectavam os focos de doenças provocadas pela corrupção do ar. Portanto, as medidas propostas pela legislação sanitária tinham por objetivo impedir todas as práticas que pudessem gerar focos de mau cheiro, tarefa extremamente ingrata, pois passava pela alteração de costumes arraigados.

A primeira preocupação das câmaras consistia em acabar com os monturos que se acumulavam pelas cidades. Nas localidades menores, eram criadas posturas proibindo que lixo e excrementos fossem lançados pelas ruas, às vezes acompanhadas da indicação de um local apropriado para fazêlo. Nas cidades maiores, o quadro proposto pela legislação municipal era semelhante, mas as mesmas situações eram detalhadas num amplo conjunto de dispositivos, que determinavam onde, como e quando jogar os diversos tipos de sujidades urbanas.

Os locais preferencialmente escolhidos para fazer esterqueiras eram as imediações das portas das cidades. Pelo que se conhece do estudo de diver- 
sas localidades, a própria legislação municipal costumava indicar estes locais para a deposição dos lixos urbanos. O crescimento urbano, com o conseqüente aumento do lixo, ou o sempre presente medo da peste, levaria muitas câmaras a tentar alterar tal costume. Na Lisboa do século XV, esta questão foi amplamente detalhada pelo poder municipal. Reiteradamente as posturas proibiam que se lançasse "esterco nem azevel* nem outras lixarias quaisquer que sejam”, diante das portas da Oura, da Alcáçova, da Cruz, de Alfama e da Erva. As proibições se estendiam às barrocas de São Francisco, às traseiras da osia [nave principal] do Carmo, ao rossio e suas abertas e ao caminho que ia de São Mateus para São Domingos, onde parecia haver o costume de abandonar animais mortos. Também havia a preocupação de que não se formassem esterqueiras junto à muralha velha, nem à nova, bem como junto às barbacãs ou no fosso dos muros. ${ }^{28}$ Em contrapartida, estavam destinados para o lançamento do lixo os fornos velhos da cal e alguns segmentos da ribeira do Tejo, especialmente demarcados para isso, com a condição de que fossem jogados na vazante, para que os dejetos fossem levados pela maré "que naquele dia ou noite vier". ${ }^{29}$ Quem contrariasse tais preceitos estava sujeito a multas diversas.

Não é preciso recorrer à cosmogonia da cultura ocidental, como fez o historiador francês Alain Corbain, para justificar a secular repugnância dos moradores das cidades pelo estirâncio, a faixa beira-mar ora coberta ora descoberta pelas marés. ${ }^{30}$ Talvez a percepção desta faixa como local de deposição dos "excrementos do mar" se deva a um simples processo de antropoformização da natureza. Como num espelho, o mar imita o homem no gesto diário de lançar os rejeitos pútridos no limite onde se encontram terra e água. Ambos são cúmplices em transformar o estrão em cloaca universal.

A reiteração das posturas que regulamentavam os locais de lançamento de dejetos e as freqüentes referências documentais a monturos que se disseminavam por toda a cidade, exalando ares pestilenciais, autorizam supor um generalizado desrespeito aos regulamentos conselhios. Ocorre que as instituições municipais ainda não haviam assumido o papel de prestadoras de serviços públicos e a limpeza da cidade e o transporte de dejetos até os locais demarcados para o seu lançamento era considerada como tarefa privada dos moradores da cidade. ${ }^{31}$

Por sua vez, os moradores consideravam tal tarefa como um ônus, do qual muitos procuram escapar. As raras tentativas de criação de serviços 
municipais de coleta de lixo não tiveram continuidade. Em contrapartida, nas cidades maiores, o transporte de dejetos inscreveu-se no multifacetado mercado de pequenos serviços urbanos. Junto com carregadores de lenha ou de água, vamos encontrar escravos de ganho que passavam pelas casas a recolher o lixo. Na Lisboa seiscentista, Brandão de Buarcos, sempre exagerado em seus números, fala em "mil negras que andam pela cidade com canastra alimpando a cidade". ${ }^{32} \mathrm{O}$ mesmo autor procura nos mostrar que Lisboa era rica até em seu lixo, o que teria gerado uma outra 'profissão': a de garimpador dos restos urbanos.

Andam nesta cidade 20 homens ao longo do mar, com gamelas, a lavar o lixo e esterco que lançam fora das casas. Aonde acham muitas coisas, tais como colheres de prata, cadeias de ouro e anéis, pontas de ouro, vinténs, tostôes e às vezes bons portugueses ${ }^{* *}$. De maneira que estes vinte homens não vivem de outra coisa. ${ }^{33}$

Nas demais cidades portuguesas as legislações municipais nos mostram quadros sanitários idênticos ao de Lisboa, assim como grandes semelhanças na forma de agir das câmaras. A legislação coimbrã também era farta em posturas que procuravam delimitar os locais onde os moradores da cidade deveriam lançar os seus dejetos.

166 - Item - Defendemos que nenhuma pessoa faça esterqueiras nem lance cisco dentro na cidade nem à Porta de Belcouce, nem à porta nova, nem ao cais e podê-lo-ão lançar ao longo do rio do padrão que está defronte das casas de Manuel Dias para baixo contra o rio e não o lançarão nas bocas das ruas, nem na rua que vai da porta do castelo para $S$. Martinho e poderão lançar o dito cisco em uma barroca que está no fundo da Couraça, de maneira que não fique nenhum na calçada, nem no peitoril sob pena de, quem o contrário fizer, e for achado ou se lhe provar, pagar por cada vez cem réis. ${ }^{34}$

Tudo muito semelhante entre a Coimbra quinhentista e a Lisboa quatrocentista, da proibição de se lançar lixo junto às portas da cidade, à demarcação de um segmento do rio para utilizar como escoadouro das imundícies. É provável que já no séculos anteriores as portas da cidade e as barrocas da couraça servissem de esterqueiras, pois, muitas das posturas municipais coimbrãs são simples confirmações de outras que vigiam há longa data. 


\section{A exemplo das cidades do Reino}

Se acompanharmos a expansão colonial portuguesa, vamos encontrar um panorama praticamente idêntico em relação ao tema da salubridade urbana. Para não dizer que não havia diferenças, há que considerar uma mudança, mas uma dessas que nada alterava. $O$ destino do lixo não era mais as margens do Tejo, Mondego, Lima ou Douro, mas as do Mandovi, do Capiberibe ou Beberibe, ou as baías de Luanda, Todos os Santos ou da Guanabara.

Nos Açores e na Madeira a situação parece ter sido menos crítica do que na Península. A disposição das cidades ao longo de costas cortada por sucessivas ribeiras facilitava o escoamento de dejetos e águas servidas. Também se pode atribuir esse quadro mais favorável ao fato de que, nas ilhas, não chegou a ser tão intenso o processo de adensamento e verticalização. No início do século XVII, o padre Cordeiro, em sua História Insulana, faz uma comparação entre Angra e o continente, atribuindo uma suposta limpeza da capital terceirense à existência de amplos quintais, ou seja, à baixa densidade de ocupação.

[Em Angra] sempre as ruas estão muito limpas até de noite, sem necessitarem de outros alimpadores, porque das janelas não se lança na rua cousa alguma, e assim nunca se ouve Água vai, porque não há casa que não tenha seu quintal e algumas muito grandes e muitas têm da fonte água dentro, e nunca nas ruas se vê despejo humano algum, o que tanto se estranha em outras terras. ${ }^{35}$

O comentário deste historiador deve ser lido tendo em conta que a limpeza das cidades era tomada como índice de urbanidade. Apesar das suas afirmações, as posturas de Angra reiteravam a obrigação de gritar "água vai”, apenando os infratores em um tostão, em 1655, e em duzentos réis, em 1788, quando a câmara determinou que após o aviso o morador deveria demorar-se "algum espaço em a lançar". As posturas de 1655: proibiam que se lançassem sujidades em qualquer rua, travessa ou praça da cidade, nem por cima dos peitoris do Colégio Velho, do porto e das prainhas. A legislação municipal angrense também procurava impedir que os moradores jogassem detritos na alcaiçaria e na "ribeira" da cidade. No século XVII, a câmara não indicava quais os locais onde eram permitidas as esterqueiras e o 
lançamento de animais mortos, mas, muito provavelmente, o lixo deveria ser encaminhado para os mesmos locais prescritos no século XVIII: "qualquer sítio público fora da cidade, onde não embaracem as servidões”, ou a "Grota do Vale".

Há que considerar que a existência de quintais, como anotou o padre Cordeiro, não era garantia de salubridade. Vilhena, comentando o deplorável estado sanitário de Salvador, refere-se à corrupção da atmosfera em decorrência, justamente, das muitas imundícies que "se lançam por diversas passagens, além das que há em quase todos os quintais, e que percutindo o sol faz subir aquelas partículas pútridas de que impregnam a atmosfera contaminando o ar". ${ }^{36}$

$\mathrm{Na}$ cidade da Bahia, o problema das esterqueiras em terrenos particulares parecia existir há longa data. Decidiram os oficiais do Senado, em 1626, "que toda a pessoa, que tivesse Casas nesta Cidade, donde fizessem esterqueiras as mandassem alimpar, com pena de seis mil réis”. Inicialmente, a câmara autorizava que as esterqueiras fossem feitas junto às portas da cidade o que, mais tarde, seria proibido por um dispositivo que mandava lançar os dejetos nas hortas da Fonte Nova ou conduzi-los em canastras até a praia na altura da "fonte que chamam dos Padres e da praia de Nossa Senhora da Conceição até a Preguiça”. ${ }^{37}$ Assim como em Lisboa, o transporte dos excrementos era feito ou por escravos domésticos ou por negros de ganho. Carregando canastras, eles passavam de porta em porta oferendo os seus serviços.

Nas antípodas de Salvador mudam alguns personagens, decerto, mas, para os conhecidos problemas, as mesmas soluçôes. Em 1783 a câmara da cidade do Nome de Deus da China tentaria resolver o problema do lixo urbano criando o ofício de Vigia das Ruas e Praias. Através da regulamentação deste novo emprego municipal nos é dado saber o destino que deveria ser dado aos dejetos da cidade. A legislação macauense era relativamente permissiva, pois tolerava as esterqueiras nos baldios em geral, sem determinar locais mais precisos, mas como alternativa, apontava o lugar de sempre: o mar.

$5^{\circ}$ - Terão mais a obrigação de saber quem são os chinas, ou cristãos, que deitam o sujo de suas casas, ou boticas, nas ruas públicas desta 
mesma cidade deixando de o fazer nas praias, ou baldios desta mesma cidade. $^{38}$

A existência de fiscais encarregados da limpeza pública não era propriamente uma novidade. Desde a Idade Média, Lisboa e outras cidades portuguesas da Europa tinham os seus almotacés da limpeza. Em Goa, ainda nos seus bons tempos, foi atribuído aos meirinhos, aparentemente à revelia dos mesmos, o poder de polícia sanitária da cidade.

O senhor vice-rei mandava por ele [procurador] dizer à cidade que provessem da limpeza dela, porquanto estavam as ruas e travessas cheias de imundícies de que se causavam enfermidades e desnobrecimento da mesma cidade e para esse efeito chamassem todos os meirinhos e lhes pusessem penas de perdimento de seus cargos e as mais que parecesse à mesa, que tenham particular cuidado daqui em diante de correr os bairros que a cada um for dado vigiando de noite e de dia as pessoas que lançam as tais imundícies para as apenarem e executarem conforme as posturas.

Goa, 3 de novembro de $1601 .^{39}$

Na Salvador do início do século XVII a fiscalização da limpeza estava a cargo do rendeiro do verde. ${ }^{40}$ Mais para o final do século, atendendo a proposta do juiz do povo, preocupado com a onda de epidemias que vinha se abatendo sobre a cidade, os oficiais do Senado de Salvador chegaram à conclusão de que "era muito conveniente que fizessem dois almotacés de limpeza, a exemplo das cidades populosas do Reino de Portugal”. O que foi feito imediatamente, sem que, aparentemente, tenham conseguido por cobro às "muitas imundícies que se lançam pelas ruas e praças dela". ${ }^{41}$ As descrições de Salvador continuariam a apresentá-la como uma cidade coberta de monturos de lixo.

Em relação a outras cidades brasileiras, pouco se conhece a respeito do modo de agenciar os detritos urbanos. No entanto, os esparsos registros disponíveis permitem supor que, tanto o quadro legal existente, quanto a desobediência a ele, eram semelhantes ao que se estabeleceu até aqui. Em Vila Rica, a câmara municipal criou norma proibindo que se jogassem dejetos "nas ruas ou becos públicos, nem nos canos, que desaguam para eles debaixo da pena de meia oitava de ouro". ${ }^{42}$ No Rio de Janeiro sabe-se que exis- 
tiam posturas proibindo que se acumulasse lixo junto às portas das casas e disciplinando o lançamento de águas servidas. ${ }^{43}$ Mas, sabe-se também do hábito de utilizar os canais de drenagem das lagoas como esterqueiras, "onde se fermentava a putrefação do ar ambiente da cidade". Monturos "dispersos pelo centro da povoação aumentavam as causas de moléstias graves" ${ }^{44}$ No início do século XVIII, a câmara de São Paulo procuraria resolver, com uma única lei, três problemas da cidade: a limpeza das testadas, o entupimento de cavas e a destinação do lixo.

E outrossim, façam tapar todos os covões, das mesmas testadas; como também façam roçar as matas; e carpir os chão, que por direito lhes pertencem, mandando botar somente os ciscos, ou lixo nas partes assinaladas, a saber nos covôes da Misericórdia nova; e em outros que se acham por dentro desta cidade, para que se vão estes entupindo, que depois destes arrasados se lhes consignará paragens de outros para o mesmo efeito. ${ }^{45}$

A câmara foi precisa em determinar que apenas o mato carpido e os resíduos secos (ciscos) deveriam ser utilizados para nivelar os covões. $\mathrm{O}$ destino dos excrementos e outros lixos orgânicos era o Tamanduateí.

\section{0 inventário olfativo das colônias}

No século XVIII assiste-se a emergência daquilo que pode ser considerado uma ciência do saneamento propriamente dita, que buscava superar as sistematizaçōes empíricas medievais e renascentistas e conformar uma política sanitária, em substituição às atuaçōes episódicas dos séculos anteriores. Quem melhor definiu o sanitarismo do século XVIII foi o historiador francês Alain Corbain.

[A] política sanitária que então se estrutura inspira-se num passado já distante, assombrado pelo nauseabundo; ela assume práticas herdadas da ciência antiga, ressurgidas no campo dos regulamentos urbanos [as nossas posturas municipais] por volta do século XIV. No entanto, esse higienismo não se restringe à reutilização (do dejeto): a evolução das convicções médicas e, mais ainda, os progressos da química já asseguram sua modernidade. 
A estratégia sanitária que se modela então não mais se reveste com o caráter episódico daquela que se desenvolvia quando grassavam epidemias; ela pretende chegar à permanência; ela opera uma síntese; ela coordena as decisões de uma forma edilitária. ${ }^{46}$

No mundo português, é duvidoso que no século XVIII o sanitarismo tenha atingido a dimensão apontada por Corbain. Aliás, é bom que se diga, na maior parte da Europa está longe o momento em que o novo salubrismo ganhou eficácia. A permanência dos mesmos limites olfativos medievais no interior dessa emergente ciência sanitária é por demais evidente, para permitir uma nova efetividade. Continuam os impasses sanitários, como no caso de Goa, a cidade consumida pelas pestes, onde o novo ferramental não foi suficiente para tirá-la da condição de lugar maldito para a vida humana. $\mathrm{O}$ século XVIII produziu mais diagnósticos de insalubridade do que ações saneadoras. O que se observa é uma verdadeira obsessão pelo nauseabundo, o que conduziria os funcionários coloniais portugueses a produzirem um verdadeiro inventário olfativo das colônias. Junto com eles começam a circular pelas colônias a geração de médicos e naturalistas formados pela recém-reformada Universidade de Coimbra, os quais eram detentores dos saberes científicos da época. No conjunto, esses funcionários e cientistas tornam-se exímios cheiradores que se dedicam com paixão ao judicioso exame do nauseabundo e à sua descrição. Não houve cloaca, pântano, poço, encanamento ou maloca que não fosse cheirado na insaciável busca das partículas mefíticas que contaminavam a tudo e a todos.

\section{Inundação volátil de partículas corruptas}

Luanda, por exemplo, foi apresentada como uma cidade decadente cheia de edificações pomposas prestes a desabar. A cidade foi descrita como se estivesse num estado mais deplorável do que o de Lisboa, que "já não mostra vestígios tão sensíveis" do terremoto. ${ }^{47}$ Elias da Silva Correia, o militar brasileiro autor deste relato, nos legou um curioso arrolamento olfativo de Luanda, caracterizando-a como uma espécie de inferno sanitário.

$\mathrm{O}$ artigo da limpeza sendo assaz vigiado nos benignos climas, neste é o menos atendido. Os habitantes da Capital [Luanda] não se enojam de acacular monturos à roda das suas habitaçôes: fermentados com as chu- 
vas se evaporam com insuportável fétido; e todos participam da inundação volátil destas partículas corruptas. ${ }^{48}$

Se as casas da elite afro-portuguesa são alvo de ácidas condenações, imaginem as dos nativos.

As cubatas [....] além de humildes, negras e sórdidas, passam a ser escuras e oprimidas: a sua triste arquitetura não lhes permite mais do que quaisquer frestas com o nome de janelas; ali existe o ar em sossego; e assim mesmo amam os miseráveis, que as ocupam, este gênero de prisão em que gemem com sezôes malignas, disenterias, etc., respirando a corrupta atmosfera que os cerca. ${ }^{49}$

O quadro é complementado com a descrição de fossos de água estagnada nos barreiros de onde se extrai material para as construções, casas feitas de palha que apodreciam desprendendo odores nauseabundos, negras quitandeiras vendendo peixe apodrecido, cadáveres abandonados no adro da igreja a serem consumidos pelos cães e porcos que vagam por todo lado. Para finalizar, Correia menciona um ponto central da questão sanitária, o qual, como veremos, não é monopólio angolano.

As armaçóes dos negros, que sucessivamente concorrem para a Cidade, ocupam tantos quintais, quantos são os armadores, que os exportam, espalhados pela cidade inferior. $\mathrm{O}$ hálito desta imunda negraria seria bastante para pôr em paralelo o ar de Sintra com o de Angola, se ali existisse. $\mathrm{O}$ projeto de erigir um Lazareto, proporcionado, ventilado, e distante para reclusão destes indivíduos, jamais foi ideado; ou proposto aos Comerciantes deste Africano Reino. Desta falta provêm as deserçôes que fazem, e ensaiam fazer esses miseráveis, submergidos em imundícies, misturados com os que padecem agudas moléstias, e sem reserva dos que sofrem a funesta epidemia das bexigas, que grassando livremente reduz ao túmulo a maior parte. ${ }^{50}$

\section{Tudo que a natureza thes lembrava}

Atravessando o Atlântico, há, no continente de origem do militar, a contrapartida do que ocorre em Angola. Neste aspecto, Luanda não difere dos outros portos voltados ao tráfico de escravos, sejam os de exportação sejam os de importação. No Brasil, o mesmo quadro é encontrado no Rio 
de Janeiro, São Luís, Recife, Salvador ou em outros portos menores. O marquês do Lavradio, em seu relatório de transferência do cargo de vice-rei, em 1779, deixou sugestiva descrição do impacto sanitário do tráfico no Rio de Janeiro.

Havia mais na cidade o terrível costume de que todos os negros que chegavam da costa d'África a este porto, logo que desembarcavam, entravam para a cidade, vinham para as ruas da cidade e principais delas, não só cheios de infinitas moléstias, mas nus; como aquela qualidade de gente, enquanto não tem mais ensino são mesmo que qualquer outro bruto selvagem, no meio das ruas onde estavam sentados em tábuas, que ali se estendiam, ali mesmo faziam o tudo que a natureza lhes lembrava, não só causando o maior fétido nas mesmas ruas e suas vizinhanças, mas até sendo o espetáculo mais horroroso que se podia apresentar aos olhos. As pessoas honestas não se atreviam a chegar às janelas; as que eram inocentes ali aprendiam o que ignoravam, e não deviam saber, e tudo isto se concedia sem lhe dar providência, e só por condescenderem com as ridículas utilidades que tinham os negociantes, a que pertenciam aqueles escravos, com os recolherem de noite nas lojas ou armazéns que ficavam por baixo das casas em que assistiam, porque com os alugueres que percebiam par ali se recolherem os escravos, vinham a ficar de graça, ou por preços muito diminuto, morando no resto das casas que sobejavam à acomodação daqueles hóspedes. ${ }^{51}$

Assim como em Luanda, os comerciantes de escravos do Rio de Janeiro mantinham a sua mercadoria em suas próprias casas. Na África, eram as senzalas localizadas nos quintais da cidade baixa; no Brasil, serviam de depósito os sobradões portuários, cujos andares superiores eram utilizados como moradia. Neste aspecto, não havia maiores diferenciações com qualquer outra atividade comercial. Mantinha-se um costume já adotado na Idade Média que era o de agregar num mesmo imóvel as atividades comerciais e artesanais com a residência dos envolvidos. Todavia, em oposição a outras atividades econômicas, que por serem consideradas insalubres foram transferidas para os arrabaldes, o comércio de escravos foi mantido até muito tardiamente no interior do quadro urbano. Para esta permanência devem ter pesado a capacidade dos negociantes em impor as suas "ridículas utilidades”, ou seja, a redução dos custos de alojamento e vigilância. Não esqueça- 
mos que estes mesmos comerciantes fazem parte das elites conselhias de todo o império colonial português.

Neste final de século XVIII, as preocupações de Elias Correia não eram isoladas e o remédio proposto para Luanda já era adotado em algumas cidades. Entre as diversas intervençôes urbanas realizadas pelo marquês do Lavradio no Rio de Janeiro, pode-se contar a efetivação de uma das medidas “jamais ideadas" para Luanda: mudar os depósitos desta especial mercadoria para lugar distante. O marquês ordenou que comércio de escravos fosse transferido para o Valongo. Depois de comprados, eles deveriam aguardar no Campo de S. Domingos, até que fossem levados para as fazendas ou minas. Poupava-se, assim, o morador das cidades do triste espetáculo deste comércio, o qual, em muitos casos, era a própria razão de ser econômica do lugar.

\section{Vapores crassíssimos}

Na porção oriental do Império, repetem-se os diagnósticos olfativos. A mais antiga povoação portuguesa da África Oriental era a feitoria de Moçambique. Em comum com diversos assentamentos portugueses do século XVI, Moçambique estava localizada numa pequena ilha junto da costa, o que o novo salubrismo não via com bons olhos. Um autor anônimo, da segunda metade do século XVIII, deixou uma análise da ação do clima sobre a saúde dos habitantes da vila. Muito provavelmente, o texto saiu da pena de um cirurgião, pois ele critica a substituição do cirurgião da ilha, talvez ele próprio, por físicos acadêmicos enviados da metrópole, pouco versado nas doenças tropicais.

O tempo mais favorável neste país é de maio até novembro, em que então principia a ser penoso mais o passar-se nesta ilha, passando neste mês o sol ao trópico sul até ao meado de dezembro, tempo em que aquece a atmosfera, tanto quanto mais o sol se avizinha, e retrocedendo este planeta, segue-se comumente principiar a maior abundância de chuvas, e com intenso calor e vapores crassissimos, que subindo se vão condensando em grossa atmosfera, e cheia de exalações podres, e com a causa da má combinação que faz água salgada com a doce da chuva, nesta ilha, procede de aos seus habitantes encherem-se de náuseas, nasce a dor de cabeça, vem a febre e caem enfermos, que em as mais das naturezas demorando-lhes os remédios, azeda-se a biles e procede as biliosas, 
e nascendo mais a fermentação, forma-se a febre podre, havendo-se passado pelos miseráveis todos os ácidos inflamatórios, de forma que a qualidade desta febre vem a produzir as perniciosas, os delírios e ultimamente as malignas, e conforme as contagiosas estações dos anos, como também as deploráveis naturezas por desordenadas nos seus regimes, e ao mesmo tempo impróprios e insípidos os alimentos deste país, vêm a formar-se tão repentinamente as gravíssimas moléstias, que em breves dias não lhes valendo as aplicações de alguns condizentes remédios, acabam depressa as vidas; durando enfim este flagelo em alguns anos, e muito mais nos antecedentes até fim de maio e junho: e por estas ponderáveis circunstâncias, é a displicência, assim como é pernicioso de passear-se esta ilha das nove horas da manhã até as quatro da tarde nos meses de dezembro até fim de abril. ${ }^{52}$

A esses fatores de ordem natural, o narrador, assim como boa parte dos religiosos e funcionários ilustrados que descreveram a porção tropical do império, adiciona outros ainda que são de ordem cultural. A saúde era consumida pela lascívia que provocava o "contágio gálico" e pelo uso imoderado de bebidas alcoólicas. ${ }^{53}$

\section{Qual outra Tróia}

Para não dizer que o salubrismo iluminista foi totalmente incapaz de gerar uma nova eficácia sanitária pode-se dizer que, em alguns momentos, ele produziu mais do que o mero levantamento olfativo. No século XVIII foram construídos os aquedutos de Lisboa e do Rio de Janeiro. Também foram dessecados alguns pântanos, como o Piri em Belém do Pará, ou em Mormugão na Índia, ou de alguns mangues do Rio de Janeiro, como é o caso do que foi utilizado para implantar o Passeio Público. Essas ações de maior envergadura estavam quase sempre associadas à idéia de construir capitais ou de recuperar cidades que se tornaram moribundas por problemas de insalubridade.

Os climas tropicais não foram apenas a causa da morte de conquistadores ilustres, ou do simples colono morto no anonimato. Em parte, pelo mesmo motivo, tanto algumas importantes cidades quanto pequenas vilas desapareceram por completo. Um dos exemplos mais notáveis de cidade perdida pela insalubridade foi São Tiago de Cabo Verde, cujas ruínas esti- 
mulam a sensibilidade livresca dos funcionários ilustrados dos séculos XVIII e XIX, que comparam-nas com as de Tróia ou da "famosa Palmyra!" 54

A cidade está qual outra Tróia, só com a diferença do sucesso. Está deserta de seus habitantes que conhecidos de uma conhecida e vergonhosa inação a desampararam, buscando os campos, onde vivem de tal sorte aborrecidos, que para ela voltarem são necessárias ordens positivas [....]. ${ }^{55}$

Se alguns atribuem o estado a que chegou a cidade à inação dos habitantes, um dos discursos mais correntes dos funcionários portugueses sobre as colônias em geral, outros apontam fatores de ordem locacional e sanitária.

A Cidade é exposta todos os dias aos ardentes raios do sol, rodeada de montanhas tão altas que não deixam penetrar o vento, a não ser pela ribeira que também em pequena distância acaba entre as contíguas serras. Este vale ou ribeira regadia exala vapores, que naturalmente são prejudiciais; as casas por dentro estão sempre úmidas; os freqüentes danos que causavam as grossas pedras destacadas dos rochedos, e além disso o péssimo porto, motivaram o abandono desta povoação. ${ }^{56}$

Na realidade, o que causou o abandono de São Tiago foi a quebra da equação mencionada por Duarte Pacheco Pereira, que conjugava a insistência em ficar com as vantagens econômicas que o local proporcionava. $\mathrm{O}$ sítio da cidade era reconhecidamente insalubre desde a sua fundação. Mesmo assim, ela prosperou como um grande entreposto de escravos no Atlântico e como centro de tributação do tráfico.

Em Moçambique, a vila de Sena foi sempre considerada uma localidade fatal aos colonizadores. Em 1752, a coroa portuguesa, antes de elevá-la à condição de vila, considerou hipótese de mudá-la dos baixios onde se situava para a serra de Marambala "em melhor sítio, muito saudável" foi oficialmente abandonada pela coroa face aos altos custos necessários à operação e a uma provável resistência dos nativos. Afinal, como afirmou Inácio Caetano Xavier, encarregado pela coroa de estudar a mudança, o sítio da vila não era bom, mas "os primeiros moradores acharam alguma conveniência em escolher este, e não outro, que fosse melhor ${ }^{58}$ Como forma de viver neste local considerado inóspito, os habitantes de Sena passariam a utilizar certos preceitos sanitários 'inovadores', se considerarmos que se vivia numa época pré-microbiana. Embora, desde a Idade Média, houvesse o 
costume de ministrar "água cozida" aos doentes, esta forma de prevenção não era, de forma alguma, usual no século XVIII.

É esta vila situada na margem do rio, em uma baixa, situação antiquíssima; cercada à roda de montes altos, e cheios de matos, o que a faz ser doentia. Bebe-se a água do rio, por não haver na Vila fontes, e é o outro motivo que concorre para ser doentia. Costuma-se deitar esta água em grandes talhas para assentar, e ao depois, filtrada por umas pedras, que há para isso, se bebe; porém algumas pessoas usam da precaução de mandar ferver, ou simplesmente ou com grama, e ao depois de fria a bebem, e dão-se melhor com esta receita. ${ }^{59}$

No outro lado do mundo, a capital do Estado da Índia padeceu de um mal semelhante. A principal causa do processo de decadência de Goa, a dourada, foi a perda da maior parte das possessões portuguesas do oriente para os holandeses, que, durante o século XVII, submeteram a cidade a prolongados períodos de sítio. Mas não foi apenas isso que provocou o progressivo abandono da cidade.

Desde sua fundação, Goa foi um sorvedouro de homens brancos, que ao chegar eram submetidos àquele processo de seleção darwiniana já comentada. Assim que desembarcavam dos galeões, soldados, marinheiros, fidalgos, sacerdotes e comerciantes eram logo acometidos de febres e disenterias que consumiam um bom percentual dos recém-chegados. Para 'fazer a Índia', antes era preciso sobreviver.

O problema agravou-se a partir de 1535 , quando a cidade foi acometida por uma severa epidemia de cólera. Desde aquele momento a questão da salubridade sempre esteve nas preocupações da coroa portuguesa e dos moradores. Todavia, a mais famosa epidemia de Goa foi a de 1570, atribuída ao apodrecimento de um elefante. A imagem do elefante morto, decompondo-se lentamente na lagoa da Carambolim, permaneceu indelével na memória dos goeses, transformando-se num fantasma sanitário que periodicamente assombrava a cidade.

Apesar deste fantasma, Goa conseguiu permanecer e se expandir, mas apenas enquanto a perspectiva de enriquecimento conseguiu sobrepor-se aos riscos. Ao longo do século XVII, a conjunção entre as guerras holandesas e os periódicos surtos de cólera causou o despovoamento da cidade. Acabado o ciclo das riquezas do oriente, a insalubridade de Goa assusta cada 
vez mais. A cidade não mais oferecia a ilusão da riqueza fácil e, portanto, já não valia a pena correr o risco de viver neste local pestífero. Lentamente a cidade se dissolve.

Goa e São Tiago foram casos clássicos de desurbanização. Em São Tiago a população urbana simplesmente desertou a cidade, trocando-a pelas propriedades rurais. Já em Goa ocorreria um processo de suburbanização. A população restante mudou-se aos poucos para o equivalente indo-português das quintas de recreio. As moradias secundárias tornaram-se permanentes, enquanto o núcleo urbano foi-se arruinando. Em ambos os casos, o desaparecimento físico da cidade não foi acompanhado do desaparecimento imediato das instituições urbanas. As câmaras municipais de Goa e da Ribeira sobreviveram às respectivas sedes, principalmente por uma incapacidade operacional do estado português nestas colônias, que à altura eram um ônus a carregar em nome das glórias passadas. As duas cidades sofreram atabalhoadas tentativas de transferência, marcadas pela hesitação e pelo insucesso.

\section{Do juízo que formaram das doenças e mortes}

É justamente o caso da tentativa de reconstruir a capital do Estado da Índia que permite perceber os limites do sanitarismo do século XVIII. Durante o período pombalino, os portugueses propuseram-se a reconstruir a velha Goa em seu sítio original, num ato simbólico de revivescência do Império do Oriente. Entretanto, o projeto esbarrou na alta mortalidade dos trabalhadores indianos convocados para a obra, o que levaria ao seu abandono.

Em 1779, já no governo de D. Maria I, portanto, o projeto foi retomado. $\mathrm{O}$ Capitão-Governador da Índia responsável por dar continuidade à reconstrução de Goa enfrentaria pessoalmente a questão de salubridade do lugar. Tanto ele, como o regimento sob seu comando, estacionado no colégio de São Roque, dentro da cidade velha, são atingidos por diversas doenças. Os trabalhadores indianos requisitados das aldeias vizinhas para a reconstrução da cidade foram acometidos por um surto de cólera e desertaram. Frente a todas essas dificuldades, o governador acabaria ordenando que a câmara, em conjunto com diversos peritos, produzisse um relatório cir- 
cunstanciado sobre o problema sanitário de Goa, o qual deveria contemplar os seguintes quatro tópicos.

$1^{\circ}-$ Do que viram e examinaram;

$2^{\circ}$ - Do juízo que formaram das doenças e mortes;

$3^{\circ}$ - Quais serão os remédios que pareçam mais próprios para purificar o ar para preservar os cidadãos e habitadores da cidade contra as doenças e para cessarem as causas delas;

$4^{\circ}$ - Se a cidade no atual e presente estado se pode habitar sem grande risco dos cidadãos e vida dos vassalos de Sua Majestade que forem residir, ou, pelo contrário, se exporão a adoecer e morrer uma grande parte indo morar. ${ }^{60}$

Os pareceres produzidos em resposta à solicitação do governador constituem uma das mais ricas fontes para se conhecer o salubrismo oitocentista português. Tomados em conjunto com os outros inventários olfativos produzidos pelos funcionários coloniais, durante os reinados de D. José e de D. Maria I, é possível perceber que a nova ciência do sanitarismo urbano não ultrapassava os limites olfativos herdados dos séculos anteriores.

\section{Louros e alcatrões}

É verdade que alguns dos velhos métodos medievais, utilizados na purificação de atmosferas corrompidas, haviam entrado em desuso ou eram criticados pelos funcionários ilustrados do final do século XVIII. Vamos encontrar, em muitos relatos, um certo consenso sobre a inutilidade da queima de alfazemas e outras ervas perfumadas, procedimento que havia sobrevivido por muitas centúrias e ainda era uma prática corrente em muitas localidades do império. "Os Magistrados, ignorando talvez de onde dimanam as pútridas exalações que sentem, se contentam em as corrigir com alfazema e açúcar; porém, a experiência nos adverte que esses momentâneos aromas não evitam as suas péssimas conseqüências." ${ }^{61}$

Neste comentário sobre os odores nauseabundos da Luanda setecentista, Elias Correia estava convicto da ineficácia do uso de contra-aromas e de que a única forma de combater as doenças era a limpeza e a conseqüente desodorização da cidade. No caso de focos de odores putrefatos resultantes de atividades econômicas consideradas essenciais (tráfico de escravos, co- 
mercialização e conservação de carnes e peixe) o remédio era transferi-las para a periferia dos núcleos urbanos.

Todavia, as teorias aromáticas de purificação atmosférica ainda sobreviviam entre os especialistas do saneamento, mas com uma alteração radical. Desde a década de 1720 houvera uma progressiva substituição dos aromas perfumados por odores de origem química. Como forma de minorar os efeitos nocivos da irremediável atmosfera pestilencial goesa, alguns de seus estudiosos propuseram "fazer muita fumaça, queimando por toda cidade barris de alcatrão e pólvora" ${ }^{62} \mathrm{O}$ mesmo procedimento era adotado para desinfetar a atmosfera nauseabunda dos poróes dos navios negreiros. Apesar do descrédito quanto à sua eficácia, a queima de ervas aromáticas nunca foi de todo abandonada. Quando a peste se instalava, por via das dúvidas acendia-se uma vela aromática para Deus, outra química para o Diabo, ou seja, os "louros e alcatrões" queimados na epidemia que atingiu a ilha açoriana de São Miguel em $1793 .{ }^{63}$

\section{Único e impraticável remédio}

Se as teorias aromáticas já viviam o seu ocaso, as de aeração estavam mais vivas do que nunca. Entre aqueles que apresentaram pareceres sobre o caso de Goa, havia quase consenso de que o grande problema da cidade era a sua localização num baixio úmido, ao pé de um conjunto de morros que impediriam a boa circulação do ar. Dizia um deles: "Vi e observei que a cidade de Goa está situada em vale que formam quatro montes que esta situação, a qual sem dúvida é a mais triste que consideram os geógrafos, é a mais funesta para se formar qualquer povoação." ${ }^{64}$

Os mais radicais quanto à inviabilidade de se reconstruir a capital indoportuguesa em seu antigo sítio valiam-se de argumentos retirados das teorias da aeração. Um dos peritos envolvidos aproveitou para exercitar a sua ironia sobre as maneiras de eliminar as causas das epidemias de Goa. "Para se tirar as causas e cessar os efeitos, há um só único e impraticável remédio, que é demolir os montes e levantar o plano de sorte que fique a cidade enfiada para todos os ventos". ${ }^{65}$

Era o próprio costume português de construir sobre ou junto a morros, escarpas e colinas que estava sendo criticado. As cidades à beira-mar ou 
beira-rio, que seguiram os paradigmas locacionais de Lisboa ou do Porto, passaram a ser consideradas, nos discursos deste final de século XVIII ou começo do XIX, intrinsecamente insalubres por sua própria localização. A freqüente divisão das cidades portuguesas em uma parte alta e outra baixa passaria a corresponder a uma outra cisão que a dividia em salubre e insalubre.

É notavelmente sensível a diferença, que há de salubridade desta parte da cidade [a cidade alta], para aquela da parte baixa. A falta de viração, a exalação das Casas da escravatura, e a que resulta das palhas, com que são cobertas as muitas cubatas dos pretos, e menor limpeza, que, apesar de muitos cuidados, existe às vezes junto às praias, produzem nos tempos imediatos às chuvas, os terríveis efeitos, que com muita razão tornam a Cidade de Luanda temível, principalmente nos meses de abril e maio. ${ }^{66}$

No outro lado do Atlântico, um diagnóstico idêntico ao de Goa ou Luanda. Os morros do Castelo e de Santo Antônio eram acusados da insalubridade do Rio de Janeiro, pois impediam "toda a viração do mar, tão necessária debaixo da zona tórrida” ${ }^{67}$ A grande diferença entre Goa e Rio de Janeiro é que na cidade que se tornou a capital do império a idéia de "demolir os montes" não eram tomadas como pilhéria, mas algo levado a sério. Após uma longa seqüência de planos mirabolantes que começa no século XVIII, a tecnologia do século XX veio mostrar que não era tão impraticável transformar drasticamente a paisagem e a solução seria finalmente aplicada para modernizar e sanear o Rio de Janeiro.

\section{A grossura do ar}

Voltemos, porém, às ruínas da velha Goa. A teoria da aeração dava aso não só a reprovar o sítio da cidade, mas, também, à maneira como ela fora edificada. A orientação de suas ruas também era causa de insalubridade.

Além dos edifícios públicos e casas novas não tem na cidade mais ruas do que a direita e dos canos. E as casas destas ruas e de outras poucas que existem fora delas e os vestígios destas ruas mostram que a Cidade não estava situada na direção dos ventos principalmente o do Noroeste mais útil neste clima sentindo-se nela assim de dia um insuportável calor de verão. $^{68}$ 
Perceba-se que quanto à orientação das ruas há uma clara inversão quando comparamos aquilo que está sendo proposto no final do século XVIII e as prescrições dos tratados renascentistas e a legislação derivada deles nos séculos seguintes. As famosas Recopilaciones de las Leyes de Indias previam uma atitude exatamente contrária. A orientação das ruas nunca deveria coincidir com a direção dos ventos dominantes, para evitar que os mesmos fossem encanados.

Afora a má orientação das ruas, as cidades estariam comprometidas pela própria arquitetura, que era sumariamente reprovada no quesito da aeração sanitária. A principal condenação recaía sobre as camarinhas, os quartos, que tanto na matriz como nas colônias eram construídos sem que suas janelas abrissem para fora das edificaçóes.

As ditas casas existentes manifestam que foram edificadas sem consideração alguma de saúde não lhes entrando ar em alguns quartos e tendo outros encostados a quintais mais altos do que os mesmos quartos: observo pela grossura do ar deles que tendo estado as mesmas casas [....] fechadas muito tempo não têm ventilação precisa do dito elemento. ${ }^{69}$

Diagnóstico muito semelhante àquele feito pelo naturalista Alexandre Rodrigues Ferreira, a respeito da arquitetura de Barcelos, sede da capitania amazônica de São José do Rio Negro.

Sendo a terra tão úmida como é, vê-se bem quão pequeno é o cuidado que lhes merece a conservação da sua saúde, porque em vez de levantarem da terra os pavimentos dos edifícios, e tratarem de dissipar deles a umidade que os persegue, rasgando nas casas um suficiente número de portas e janelas que as arejem, pelo contrário e rentes com o chão, ajudando a encarcerar mais o ar as chamadas gurupemas, de um tecido de palha tão miúdo, que apenas se distingue o vulto de quem espreita de dentro para fora das janelas. ${ }^{70}$

Em Goa, o uso de janelas feitas com conchas translúcidas, engenhosa solução local adotada pelos portugueses nos primeiros séculos da conquista, causava espanto e era elogiada pelos viajantes europeus que conheceram a cidade. No século XVIII, as mesmas janelas foram sumariamente condenadas, pois eram consideradas insuficientes para afastar a nociva umidade que consumia a saúde dos moradores. Da mesma forma, condenavam-se as estei- 
ras - urupemas ou gurupemas — solução também local, adotada na Amazônia e no Nordeste do Brasil. Por volta de 1760, o marquês do Lavradio proibiria o uso de urupemas em Salvador. Passadas três décadas, a mesma medida seria adotada no Recife pelo governador Tomás de Melo. ${ }^{71}$ Proibições que caíram no vazio, é claro.

\section{0 costume que forma nova natureza}

Um dos principais aspectos discutidos pelos que analisaram o sítio de Goa dizia respeito à salubridade ou insalubridade da vegetação. Estava longe de ser assente e concorde entre os médicos e outros responsáveis pela salubridade urbana que o contato com a vegetação exercesse algum tipo de influência benéfica sobre a saúde das pessoas. Neste exato momento, o mundo português atravessava uma onda de construção de passeios públicos e jardins botânicos, o que pode nos levar a pensar que fosse dominante a idéia de que a vegetação era benéfica à saúde. Entretanto, há muitas evidências de que era extremamente difundida uma noção exatamente contrária a tal ponto de vista.

As árvores são uma espécie de bombas que metendo o ar na terra conservam a sua umidade mas enquanto esta umidade é útil, as folhagens que apodrecendo no chão as fazem tanto mais nocivas quanto é certo que apodrecendo levam ao ar exalaçóes impuras. Por isso é que assentam os Filósofos naturalistas que os bosques são constantemente perniciosos à saúde. $^{72}$

Para alguns, a presença de toda e qualquer árvore na cidade era considerada nociva à saúde. Para outros, existiam exceçōes. As palmeiras deviam ser poupadas "porque não impedem o vento porém fazem sombrio" ${ }^{73}$ As árvores cítricas, como os limoeiros e toranjeiras, também eram consideradas benéficas pelo perfume que exalavam. ${ }^{74}$ Neste caso, temos uma remanência da teoria dos contra-aromas. Além das qualidades intrínsecas reconhecidas nas palmeiras e nos cítricos, quer me parecer que há um outro motivo que leva a considerar tais árvores como salubres. Ambas são espécies cultivadas e pertencem, portanto, ao universo de uma natureza domesticada.

A tendência a reconhecer que as espécies domesticadas eram benéficas à saúde, aparecem em diversos outros relatos de agentes coloniais. No mes- 
mo período em que encontramos o estado português envolvido com o destino a dar ao antigo sítio de velha Goa, em outras partes do império questôes muito semelhantes eram enfrentadas pelos responsáveis pela instalação de novos núcleos urbanos, conforme determinava a política pombalina de multiplicação de vilas. A escolha de sítios urbana apropriados seguia, ainda, o receituário prescrito pelo tratadistas do renascimento, que mandava ter em conta a existência de boas águas, terrenos para a agricultura, lenha e ares salutíferos. Entretanto, a experiência acumulada mostrava a todos os enganos anteriormente cometidos. A questão que se colocava era a de como reconhecer, fora da Europa, locais que preenchessem os requisitos de salubridade.

Como resposta, procurou-se sistematizar um conhecimento indiciário que permitisse a distinção entre lugares salubres e insalubres. $\mathrm{O}$ interessante é que neste ponto os europeus são obrigados a assumir uma posição de relativa humildade. Conforme o Morgado de Mateus, Capitão-General de São Paulo, os indícios de salubridade deveriam ser buscados entre aqueles que conheciam a região a colonizar, fossem os índios, fossem animais, "que por instinto natural evitam sempre os lugares pestíferos; e de ar corrupto". 75 Esse método indiciário de abordar a questão também foi utilizado para confirmar a insalubridade permanente de Goa.

Achei que a falta de aves, que tendo a providência Divina destinado para habitarem a Região do Ar, pela má disposição da atmosfera na Cidade que elas melhor percebem que os homens como alteração desse Elemento, é total a falta delas nas suas próprias estaçōes. ${ }^{76}$

Ainda no século XVIII, não era questão resolvida a forma de identificar o local adequado para a fundação de uma nova localidade e, em resposta aos repetidos enganos, os agentes encarregados pelas novas fundaçóes acabaram por comungar da noção de que a natureza era originalmente maligna e que ela pedia um preço em vidas para ser domada. É este, por exemplo, o ponto de vista do Morgado de Mateus.

[O clima] sempre se costuma mostrar infesto e letal em todas as partes, adonde se fundam Povoações novas, pois mais ano menos ano vêm a experimentar rigorosas doenças, de que falece grande número de povoadores; enquanto as terras não se rompem, e os ares não se purifi- 
cam com os fogos, com as criações de gado, que são muito úteis para este benefício, e com o costume que forma nova natureza. ${ }^{77}$

Em parte, sob esse novo conceito aparece a prescrição muito antiga de que os animais eram capazes de regenerar os ares corruptos. Como já vimos, desde a Idade Média persistia a prática de enfrentar casos agudos de "pestenença" com e evacuação de cidades e a soltura de gado de pasto em seu interior. Apenas as práticas econômicas rurais, como a introdução de espécies cultiváveis e de gado, seriam capazes de afastar a malignidade da natureza inexplorada criando desta forma uma nova natureza.

\section{Só a Deus é patente a verdadeira causa}

Um dos pareceres mais interessantes foi produzido por Matthias Fernandes de Noronha e Cosme Gabriel Fernandes, cujas qualificações desconhecemos. Para aqueles que consideram o excesso de vegetação como causador das moléstias, eles lembram que os palmares eram uma conseqüência das pestes e não causa. Eles só passaram a existir no interior do quadro urbano quando a cidade foi abandonada devido às epidemias. Para os que propunham a antiga estratégia de soltar animais de pasto nas ruínas da cidade, eles lembraram que os cronistas do século XVI mencionavam que o método já fora utilizado na peste de 1570, quando, "para limpar os ares, povoaram de Gado o lugar, porém, que de nada o aproveitou" ${ }^{78} \mathrm{O}$ estado em que foram encontrados os canos e poços também não deveria ser apontado como causa, pois a situação deplorável em que se encontravam era resultado dos muitos anos de abandono da antiga capital do oriente. Ambos acabam por confessar o despreparo para lidar com a situação: "Dizemos que só a Deus é patente a verdadeira causa de ficar doente o sítio da cidade."79

Ao fim e ao cabo prevaleceu a idéia de que era impossível reviver esta cidade, símbolo das glórias passadas. Após grandes gastos as obras foram finalmente abandonadas. Quase três séculos depois da ocupação portuguesa, a maldição do elefante morto decompondo-se lentamente na lagoa do Carambolim, imagem que tanto impressionara os moradores e cronistas da velha Goa, a ponto de ser responsabilizado pela peste de 1570 , continuou a assombrar o sítio da cidade. Os efeitos malignos de alguma causa divina escapavam a todas as medidas intentadas com base nas práticas correntes 
que vinham da Idade Média ou nos conhecimentos científicos do século XVIII. ${ }^{80}$

\section{Notas}

${ }^{1}$ A elaboração do presente artigo só foi possível graças ao apoio da Fundación Carolina, Espanha, e do CNPq - Conselho Nacional de Desenvolvimento Científico e Tecnológico.

${ }^{2}$ MUMFORD, Lewis. A cidade na história; suas origens, transformaçōes e perspectivas. São Paulo: Martins Fontes, 1991. 3.ed., p. 314 e ss.; 388 e ss.

${ }^{3}$ ÉVORA. Regimento da cidade de Évora feito pelo corregedor da corte João Mendes em tempo del Rei D. João I. In PEREIRA, Gabriel Vítor do Monte (ed.). Documentos históricos da cidade de Évora. Fascículo I, Foros e costumes ou direito consuetudinário municipal nos séculos XII e XIII. Évora: Typographia da Casa Pia, 1885. p.188.

${ }^{4}$ TAVARES, Maria José P. F. A política municipal de saúde pública; séculos XIV-XV. REVISTA DE HISTÓRIA ECONÓMICA E SOCIAL. Lisboa, n.19, jan.-abr.1987. p.17 e ss.

${ }^{5}$ TAVARES. op. cit. p.18.

${ }^{6}$ LISBOA. Câmara Municipal. Livro primeiro do Provimento da Saúde. Carta de D. João II à Câmara. apud TAVARES, op. cit. p.26-7.

${ }^{7}$ LIVRO DAS POSTURAS ANTIGAS. Lisboa: Câmara Municipal, 1979. p.39-40.

${ }^{8}$ PEREIRA, Duarte Pacheco. Esmeraldo de situ orbis. Lisboa: Academia Portuguesa de História, 1988. 3.ed. p.95-6.

${ }^{9}$ PEREIRA. op. cit. p. 43.

${ }^{10}$ ver VASCONCELOS, Luís Mendes de. Do sítio de Lisboa; diálogos. Lisboa: Livros Horizonte, 1990. p.86.

${ }^{11}$ ANÔNIMO (século. XVI) Navegação de Lisboa à ilha de São Tomé. In ALBUQUERQUE, Luís. (ed.) A ilha de São Tomé nos séculos XV e XVI. Lisboa: Publicações Alfa, 1989. p.31-2.

${ }^{12}$ AMBRÓSIO, P. António. A fundação da "Poçom" (S. Tomé): uma capital em África. ACTAS DO CONGRESSO INTERNACIONAL BARTOLOMEU DIAS E A SUA ÉPOCA. Porto: Universidade do Porto, 1989. v.1, p. 492.

${ }^{13}$ SÁ-NOGUEIRA, Isabel B. \& SÁ-NOGUEIRA, Bernardo. A ilha do Príncipe no primeiro quartel do século XVI; administração e comércio. In: ACTAS DO CONGRESSO INTERNACIONAL BARTOLOMEU DIAS E A SUA ÉPOCA. Porto: Universidade do Porto, 1989. v.3, p.113.

${ }^{14}$ ALBUQUERQUE, Viriato A. C. de. O senado de Goa; memória histórico-arqueológica. Nova Goa: Imprensa Nacional, 1909. p.355.

${ }^{15}$ SALVADOR. Atas da câmara. DOCUMENTOS HISTÓRICOS, Salvador, Prefeitura Municipal, v.1, p.19. 
${ }^{16}$ RUY, Afonso. História da Câmara Municipal da cidade do Salvador. Salvador: Câmara Municipal, 1953. p.152.

${ }^{17}$ MELO, Francisco Manuel de. Carta de guia de casados. Lisboa: Editorial Verbo, s.d. p.157. ${ }^{18}$ Sobre o caráter civilizador das posturas municipais, ver PEREIRA, Magnus Roberto de Mello. Cortesia, civilidade, urbanidade: conversando com Norbert Elias sobre a conformação dos espaços e das sociabilidades na cidade medieval portuguesa. HISTÓRIA: QUESTÕES \& DEBATES, Curitiba, n.30, 1999. p.111-146.

${ }^{19}$ ARQUIVO COIMBRÃO, Coimbra, v.2, 1931. p.174.

${ }^{20}$ ARQUIVO COIMBRÃO, Coimbra, v.5, 1940. p.61.

${ }^{21}$ Desde o século XIV, alguns conselhos construíam sanitários públicos. Em Lisboa, as posturas medievais faziam referência a um rego das privadas. O conselho de Braga, em 1581, encarregou o procurador de fazer privadas na "torre do meio que vai para São Sebastião". No Funchal, existem referências a uma "ponte das privadas", provavelmente sobre a atual Ribeira de Santa Luzia. Ver LIVRO DAS POSTURAS ANTIGAS, p.6. ; BRACARA AUGUSTA. Braga, v.24, n.69-70, jan.-dez.1970. p.400; ARAGÃO, António.(ed.) A madeira vista por estrangeiros. 1457-1700. Funchal: Secretaria Regional de Educação e Cultura, 1981. p.216. O período coincide, também, com o aparecimento de privadas nas casas da alta nobreza. Ver MARQUES, A. H. de Oliveira. A sociedade medieval portuguesa. Lisboa: Sá da Costa, 1981. 4.ed., p.91.

${ }^{22}$ ARQUIVO COIMBRÃO, Coimbra, v.4, 1939. p.174.

${ }^{23}$ ARQUIVO COIMBRÃO, v.4, p.178. catar = apontar, indicar.

${ }^{24}$ ARQUIVO COIMBRÃO. p. 174.

${ }^{25}$ BRACARA AUGUSTA. v.21. p.406-7.

${ }^{26}$ OVINGTON, John. Uma viagem a Suratt no ano de 1689. Citado de ARAGÃO, op. cit. p. 200 .

${ }^{27}$ Mais tarde essa capacidade vetora do ar seria sistematizada numa entidade etérea denominada miasma. No período medieval ou idade moderna, não era este o termo empregado, mas já estavam lançadas as bases do sanitarismo miasmático, cujos princípios foram considerados válidos até o início do século XX.

${ }^{28}$ Nos séculos seguintes a proibição se estenderia ao Tabuleiro da Sé e aos Arcos do Rocio. DOCUMENTOS PARA A HISTÓRIA DA ARTE EM PORTUGAL. n.2. Arquivo Histórico da Câmara Municipal de Lisboa; Posturas diversas dos séculos XIV a XVIII. Lisboa: Fundação Calouste Gulbenkian, 1969. p. 71- 72, 77.

${ }^{29}$ LIVRO DAS POSTURAS ANTIGAS. op. cit. p.5-6, 9, 11-2, 17, 24, 28, 55, 59, 87, 119. * Azevel = coisa suja, porcaria, nojeira, em árabe e hebraico.

${ }^{30}$ CORBIN, Alain. O território do vazio. São Paulo: Companhia das Letras, 1989. p.23-4 e em diversas passagens do livro.

Esta repugnância se repete em relação à faixa marinha ou fluvial próxima à terra. Algumas leis municipais proibiam que se pescasse ou recolhesse água nestes locais. Ver por exemplo uma 
postura de Setúbal que proibia a pesca de camarão nas marinhas da vila. Ver PIMENTEL, Alberto. Memória sobre a história e administração do Município de Setúbal. Setúbal: Câmara Municipal, 1992. (ed. facsimilar) p.75.

${ }^{31}$ Ao longo de séculos os conselhos fizeram tentativas de impor aos moradores a obrigatoriedade de varrer as ruas, mas sem resultados aparentes. LIVRO DAS POSTURAS ANTIGAS, p.27; ARQUIVO COIMBRÃO, v.2, p.175. PIMENTEL, op. cit. p.100.

${ }^{32}$ BRANDÃO[de BUARCOS], João. Grandeza e abastança de Lisboa em 1552. Lisboa: Livros Horizonte, 1990. p.705.

${ }^{33}$ BRANDÃO, op. cit.107. ${ }^{* *}$ Portugueses = moedas da época.

${ }^{34}$ ARQUIVO COIMBRÃO, Coimbra, v.2, 1931. p.174.

${ }^{35}$ CORDEIRO, António. História Insulana. Lisboa Ocidental : Off. de Antonio Pedrozo Galram, 1717. p.274.

${ }^{36}$ apud RUY, op. cit. p.149.

${ }^{37}$ SALVADOR. op. cit. v.1, p.19; v.2, p.68 e v.5, p.180.

${ }^{38} \mathrm{MACAU}$. Câmara Municipal. Instruçōes, e obrigaçōes que devem observar as duas pessoas, que agora se nomeiam para se vigiar o que abaixo se declara. ARQUIVOS DE MACAU, v.2, n.4, abr.1930. p.211.

${ }^{39}$ Ata transcrita na íntegra no apêndice documental de SOUZA, Teotónio de. Goa medieval; a cidade e o interior no século XVII. Lisboa: Editorial Estampa, 1994. p.252.

${ }^{40}$ SALVADOR. op. cit. v.2, p.68.

${ }^{41}$ SALVADOR. op. cit. v.6, p.211.

${ }^{42}$ VASCONCELLOS, Sylvio. Vila Rica. São Paulo: Perspectiva: 1977. p.92.

${ }^{43}$ PIZARRO, Monsenhor (ARAÚJO, José de Souza Azevedo Pizarro). Memórias históricas do Rio de Janeiro. Rio de Janeiro: Imprensa Nacional, 1945-51. v.5, p.174 e v.7, p.41.

${ }^{44}$ PIZARRO. op. cit. v. 5, p.162.

${ }^{45}$ Citado de TAUNAY, Affonso de E.. História da villa de São Paulo no século XVIII. ANNAIS DO MUSEU PAULISTA. 1711-1720. tomo 5, 1931. p.526.

${ }^{46}$ CORBIN. op. cit. p. 119.

${ }^{47}$ CORREIA, Elias Alexandre da Silva. História de Angola. Lisboa: s.ed., 1937. p.78.

${ }^{48}$ CORREIA. op. cit. p. 80 .

${ }^{49}$ CORREIA. op. cit. p.79.

${ }^{50}$ CORREIA. op. cit. p.80.

${ }^{51}$ AVELLAR, Hélio de Alcântara. (org.) História administrativa do Brasil. v.5. Administração Pombalina. Brasília: UNB/FUNCEP, 1983. 2.ed. p.262.

${ }^{52}$ ANDRADE, António Alberto de. Relaçôes de Moçambique setecentista. Lisboa: Agência Geral do Ultramar, 1955. p.387.

${ }^{53}$ ANDRADE. op. cit. p.386-7. 
${ }^{54}$ CHELMICKI, J. C. C. Corografia Cabo-verdeana. Lisboa: Typ. de L. C. da Cunha, 1841. v.1, p.68-9. A referência a Palmira não era fortuita. Na última década do século XVIII, Volney publicara o seu famoso Les ruines, ou Meditations sur les révolutions des empires, obra de imensa repercussão. No frontispício existe uma gravura onde Volney aparece a contemplar as ruínas desta cidade romana da Síria, por onde circulam os pastores a que se refere Chelmicki. Ruínas, como as de Palmira ou São Tiago, convidavam a refletir sobre a efemeridade dos impérios.

${ }^{55}$ CARREIRA, António. (ed.) Documentos para a história das ilhas de Cabo Verde e "Rios da Guiné”. Lisboa: Ed. do autor, 1983. p.176.

${ }^{56}$ CHELMICKI. op. cit. v.1, p.68-9.

${ }^{57}$ ANDRADE. op. cit. p. 579.

${ }^{58}$ ANDRADE. op. cit. p. 162.

${ }^{59}$ ANDRADE, op. cit. p.356.

${ }^{60}$ GOA. Pareceres que os médicos, cidadãos como peritos, deram do estado em que se achava a cidade, e do exame e vistoria que procederam dos poços, canos, e mais lugares da mesma cidade, e seus subúrbios, em execução da carta de Sa Exa . In: ALBUQUERQUE, Viriato A. C. de. op. cit. p.361.

${ }^{61}$ CORREIA, op. cit. p.80.

${ }^{62}$ GOA. de. op. cit. p.364.

${ }^{63}$ MARQUEZ, Jacome Corrêa. (ed.) Posturas da Câmara de Ponta Delgada do século XVIII. ARCHIVO DOS AÇORES, Ponta Delgada, v.14, 1927. p.375.

${ }^{64}$ GOA. op. cit. p.353.

${ }^{65}$ GOA. op. cit. p.358.

${ }^{66}$ AMARAL, Ilídio do. Luanda; estudo de geografia urbana. Lisboa: s.ed., 1968. p.53.

${ }^{67}$ Sobre o arrasamento dos morros cariocas, ver as notas de Noronha Santos à conhecida descrição que o padre Perereca fez do Rio de Janeiro nos tempos em que a Corte portuguesa adotou-a como capital do império. SANTOS, Luiz Gonçalves dos. (Padre Perereca). Memórias para servir à história do reino do Brasil. Rio de Janeiro: Livraria Editora Zélio Valverde, 1943. v.1. p.74-5.

${ }^{68}$ GOA. op. cit. p.345

${ }^{69}$ GOA. op. cit. p.345

${ }^{70}$ FERREIRA, Alexandre Rodrigues. Viagem philosophica pela capitania de São José do Rio Negro. RIHGB, XLIX, 1866, p.182.

${ }^{71}$ ver SMITH, Robert C. Arquitetura civil no Brasil colonial. in ARQUITETURA CIVIL. São Paulo: FAU-USP/MEC-IPHAN, 1975. v.1, p.172.

${ }^{72}$ GOA. op. cit. p.347.

${ }^{73}$ GOA. op. cit. p.355.

${ }^{74}$ GOA. op. cit. p.364. 
${ }^{75}$ PROJECTO, ou plano ajustado por ordem de S. M. F. entre o Governador \& Cap.m Gen.al de São Paulo D. Luís Ant.o de Souza \& o Brigadeiro José Custódio de Sá Faria. 1772. MONUMENTA, Curitiba, v.1, 1987. p.100.

${ }^{76}$ GOA. op. cit. p.362.

${ }^{77}$ PROJECTO. op. cit. p.106.

${ }^{78}$ GOA. op. cit. p.355.

${ }^{79}$ GOA. op. cit. p.356.

${ }^{80}$ Para um apanhado geral das vertentes teóricas acerca das relações entre doenças e sociedade, $\mathrm{cf}$. CORBIN, Alain. Saberes e Odores. O olfato e o imaginário social nos séculos XVIII e XIX. São Paulo, Companhia das Letras, 1987; CZERESNIA, Dina. Do contágio à transmissão. Ciência e cultura na gênese do conhecimento epistemológico. Rio de Janeiro, Ed. Fiocruz, 1997; ROSENBERG, Charles et al. (eds.). Framing Disease - studies in cultural history. New Brunswick, Rutgers University Press, 1997; RODRIGUES, José Carlos. Higiene e Ilusão. O lixo como invento social. Rio de Janeiro, Nau, 1995; ROSEN, George. Uma História da saúde pública. São Paulo, Ed. Unesp, 1994.

\section{Resumo}

O reino da podridão foi instaurado nos espaços urbanos medievais pelos detritos das atividades econômicas e pelos excrementos produzidos pelos moradores. Simultaneamente, instalou-se o reino da peste, o que os levaria a estabelecer uma interconexão de causa e efeito entre ambas as coisas. A secular convivência com monturos e esterqueiras resultaria numa arte sanitária de cunho olfativo, baseada na correlação entre maus cheiros e doenças. Essas noçôes estiveram na base dos cuidados sanitários adotados nas cidades de Portugal, e, mais tarde, nas de suas colônias. $O$ iluminismo pretendeu substituir esta arte olfativa por uma ciência da salubridade urbana. Todavia, no universo português, esta nova ciência permaneceu presa aos limites dos saberes olfativos medievais, sem produzir uma nova efetividade. Gerou, entretanto, entre os funcionários coloniais, uma verdadeira obsessão pelo nauseabundo. Ao findar o século XVIII, os médicos e naturalistas formados pela recémreformada Universidade de Coimbra tornaram-se eximios cheiradores que se dedicariam com paixão ao judicioso exame do nauseabundo e à sua descrição. Não houve cloaca, pântano, poço, monturo ou maloca que não fosse cheirado na insaciável busca das particulas mefiticas que supunham contaminar a tudo e a todos. Palavras-chave: Alegoria, Teologia moral, Práticas religiosas. 


\section{Abstract}

A real of rottenness was created in medieval urban areas due to residue of economic activities and human waste produced by the inhabitants. At the same time, the realm of plague started, which forced contemporary men to establish a causeleffect relationship between both things. The age old way of living that shared residences and junk and manure piles would result in a smell based sanitation art, with the basic idea of smell equals to illnesses. Such notions were behind the sanitation measures adopted in the cities of Portugal and, later, in those of its colonies. The Enlightment tried to replace this smell based art by a urban health science. However, in the universe of Portuguese cities, this new science was bound to the limits of medieval knowledge, without supplying any effectiveness. It did create, though, among the colonial workers, an actual obsession with foul smell. Towards the end of the 18th Century, physicians, and naturalists graduating at Coimbra University became ace "smellers" passionately devoted to the thorough exam of sickening smells and their description. There was no sewer, swamp, well, manure pile of shack which was not smelled in the everlasting effort to find the malevolent particles which they thought contaminated everything and every body.

Keywords: Allegory, Moral theology, Religious practices.

(recebido em julho de 2004 e aprovado em dezembro do mesmo ano) 